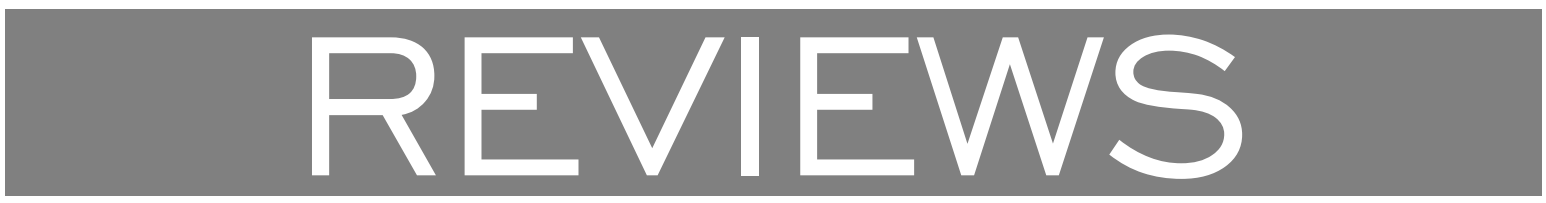

\title{
The application of ecological stoichiometry to plant-microbial-soil organic matter transformations
}

\author{
Sophie Zechmeister-Boltenstern, ${ }^{1,5}$ Katharina Maria Keiblinger, ${ }^{1}$ Maria Mooshammer, ${ }^{2}$ Josep Peñuelas, ${ }^{3,4}$ \\ Andreas Richter, ${ }^{2}$ Jordi Sardans, ${ }^{3,4}$ And Wolfgang WaneK ${ }^{2}$ \\ ${ }^{1}$ University of Natural Resources and Life Sciences Vienna, Institute of Soil Research, Department of Forest and Soil Sciences, \\ 1190 Vienna, Austria \\ ${ }^{2}$ University of Vienna, Terrestrial Ecosystem Research, Department of Microbiology and Ecosystem Science, 1090 Vienna, Austria \\ ${ }^{3}$ CSIC, Global Ecology Unit CREAF-CSIC-UAB, Cerdanyoladel Valles 08193 Spain \\ ${ }^{4} C R E A F$, Cerdanyoladel Valles 08193 Spain
}

\begin{abstract}
Elemental stoichiometry constitutes an inherent link between biogeochemistry and the structure and processes within food webs, and thus is at the core of ecosystem functioning. Stoichiometry allows for spanning different levels of biological organization, from cellular metabolism to ecosystem structure and nutrient cycling, and is therefore particularly useful for establishing links between different ecosystem compartments. We review elemental carbon : nitrogen: phosphorus $(\mathrm{C}: \mathrm{N}: \mathrm{P})$ ratios in terrestrial ecosystems (from vegetation, leaf litter, woody debris, and dead roots, to soil microbes and organic matter). While the stoichiometry of the plant, litter, and soil compartments of ecosystems is well understood, heterotrophic microbial communities, which dominate the soil food web and drive nutrient cycling, have received increasing interest in recent years.

This review highlights the effects of resource stoichiometry on soil microorganisms and decomposition, specifically on the structure and function of heterotrophic microbial communities and suggests several general patterns. First, latitudinal gradients of soil and litter stoichiometry are reflected in microbial community structure and function. Second, resource stoichiometry may cause changes in microbial interactions and community dynamics that lead to feedbacks in nutrient availability. Third, global change alters the C:N, C:P, and $\mathrm{N}: \mathrm{P}$ ratios of primary producers, with repercussions for microbial decomposer communities and critical ecosystem services such as soil fertility. We argue that ecological stoichiometry provides a framework to analyze and predict such global change effects at various scales.
\end{abstract}

Key words: carbon use efficiency; growth rate hypothesis; homeostasis; litter decomposition; nitrogen turnover; nutrient recycling; phosphorus deficiency; soil enzymes; soil microbiology; substrate age hypothesis.

\section{INTRODUCTION}

Microorganisms are the primary decomposers of organic matter in terrestrial ecosystems. The chemical composition of the plant residues and organic matter in soil in turn affects microbial activity and microbial community structure and thus the decomposition rate (Aneja et al. 2006). Plant detritus (e.g., leaf litter, woody debris, dead roots) provides a major input of energy and nutrients for microbial decomposer communities (Wardle et al. 2004), beyond soil organic matter (SOM) itself. While stoichiometric element ratios (sensu stricto the

Manuscript received 24 April 2014; revised 26 November 2014; accepted 5 December 2014. Corresponding Editor: H. A. L. Henry.

${ }^{5}$ E-mail: sophie.zechmeister@boku.ac.at element balance of the major nutrients $\mathrm{C}: \mathrm{N}: \mathrm{P}$; all element ratios presented are molar [atomic] rather than mass-based ratios) diverge during leaf senescence and litter fall (Homann 2012), microbial processing narrows these ratios during litter decomposition and the build-up of SOM (Mooshammer et al. 2014b). The structure and function of microbial communities and predominating life strategies adapt to the altered resources. At the same time, they strongly influence the speed and direction of stoichiometric shifts of the resources during decomposition.

Since decomposer $\mathrm{N}$ and $\mathrm{P}$ requirements are high compared to concentrations in plant litter or detritus, these nutrients (we refer to $\mathrm{N}$ and $\mathrm{P}$ as nutrients, and consider $\mathrm{C}$ in its role as energy source) need to be 
immobilized by decomposers from their resources until the elements are enriched above a critical value. At that point, the decomposers switch to net nutrient mineralization, and net nutrient losses may occur (Berg and McClaugherty 2003, Moore et al. 2006, Parton et al. 2007). Decomposers therefore determine $\mathrm{N}$ and $\mathrm{P}$ recycling during decomposition.

Litter decomposition rates are controlled by soil organisms as well as by environmental conditions and the chemical composition of the litter. Cross-site and cross-litter investigations covering different biomes offer insights into the questions of litter decomposition along global gradients of climate and edaphic conditions (Trofymow et al. 2002, Smith et al. 2011). While many regulating factors of litter decomposition are well studied, it remains a challenge to separate effects of stoichiometry from environmental and organic chemistry effects (see Plate 1). In particular, feedback mechanisms between $\mathrm{C}: \mathrm{N}: \mathrm{P}$ ratios of different ecosystem compartments under varying environmental conditions deserve further analysis because these mechanisms will affect nutrient cycling in a changing world.

Applying the concept of ecological stoichiometry (EST) provides a new approach to tackle the challenge of predicting nutrient recycling in different habitats. In addition, it helps introduce general ecological theories into the field of microbial ecology, where they are strongly needed (Prosser et al. 2007). The theory of EST was originally developed for aquatic ecosystems, but is universally valid, and gained increasing attention for terrestrial ecosystems during the last decade (Austin and Vitousek 2012). Sterner and Elser (2002) demonstrated that stoichiometric constraints significantly influence microbial growth and nutrient cycling in terrestrial systems. Nitrogen and $\mathrm{P}$ play especially important roles in this concept because these elements are essential for organism structure and function (Elser et al. 1996), and they are often limiting. Scrutinizing $C: N, C: P$, and N:P ratios helps us to understand little-known mechanisms, such as resource allocation of organisms under nutrientlimiting conditions.

Ecological stoichiometry has been applied to different aspects of plant growth and development, physiological traits, and nutrient acquisition. Similarly, there is increasing interest in the role of stoichiometric regulation of soil organisms and their function (Mulder et al. $2013 b$ ). Connecting the "green and brown worlds" by examining the formation and decomposition of plant detritus via elemental stoichiometry is an upcoming issue with the potential to advance the understanding of both nutrient limitation and global change effects in terrestrial ecosystems. In this review, we inspect stoichiometric mechanisms regulating the $\mathrm{C}: \mathrm{N}: \mathrm{P}$ ratios of ecosystem compartments and of nutrient dynamics across different scales. Implementing this new knowledge, namely explicit stoichiometric linkages, into practical applications such as process-based mathematical models, can advance the prediction of future developments in a changing environment (Sistla et al. 2014).

When relating above- and belowground stoichiometry in a global context, we raise the following questions: (1) How do global gradients in climate and edaphic conditions affect plant and litter stoichiometry and decomposability? (2) What are the effects of variable resource stoichiometry on microbial community structure and function? (3) How does global change affect the mechanisms of plant and microbial nutrient cycling?

In order to answer these questions, we synthesize current knowledge on the linkage between above- and belowground stoichiometry. Our approach is to track down variations in stoichiometry from plant foliage to litter, from litter to microbes, from microbes to soil, and from soil back to plants. In order to shed light on our questions, we focus on global variations in soil nutrient status as well as in climate, which we consider to be the major factors behind latitudinal gradients of $\mathrm{C}: \mathrm{N}: \mathrm{P}$ stoichiometry. Processes such as nutrient resorption before leaf abscission, the microbial conversion of different fractions of plant detritus, and microbial community composition and its effect on decomposition rate all depend on the original nutrient status of the system. We argue, however, that this is not a unidirectional relationship, but that the microbial community displays several mechanisms of feedback on nutrient limitation. We demonstrate how understanding the biological regulation of $\mathrm{C}, \mathrm{N}$, and $\mathrm{P}$ cycles helps to predict future developments in light of rapid global change. Finally, we discuss whether evidence for a growing imbalance of element stoichiometry exists.

\section{How do Global Gradients in Climate and Edaphic Conditions Affect Plant and Litter Stoichiometry AND DeCOMPOSABILITy?}

The ratios of $\mathrm{C}: \mathrm{N}: \mathrm{P}$ in environments and organisms are intimately connected with ecological processes, from the structure of communities (Sterner and Elser 2002) to biodiversity (Sasaki et al. 2010). These connections have increased interest in studying the environmental factors that determine the $\mathrm{C}: \mathrm{N}: \mathrm{P}$ ratios of terrestrial plants (Sardans et al. 2012b). Plant $\mathrm{N}$ and $\mathrm{P}$ concentrations are strongly determined by the corresponding availabilities in soil, as observed in several studies that have compared sites with similar climates but different soil $\mathrm{N}$ and $\mathrm{P}$ concentrations (Vitousek 1998, Cardenas and Campo 2007). Despite their obvious and important role, soil $\mathrm{N}$ and $\mathrm{P}$ availabilities do not appear to be the only determinants of plant N:P ratios. Most studies conducted on a global scale have reported decreases in leaf $\mathrm{N}$ and $\mathrm{P}$ concentrations (with concomitant increases in leaf $\mathrm{C}: \mathrm{N}$ and $\mathrm{C}: \mathrm{P}$ ratios, as leaf $\mathrm{C}$ is relatively constant) and increases in N:P ratios as latitude decreases and as mean annual temperature (MAT) and mean annual precipitation (MAP) increase (McGroddy et al. 2004, Reich and Oleksyn 2004, Kerkhoff et al. 2005, Ordonez et al. 2009, Yuan and Chen 2009; see also Fig. 1 for N:P; Appendix: 

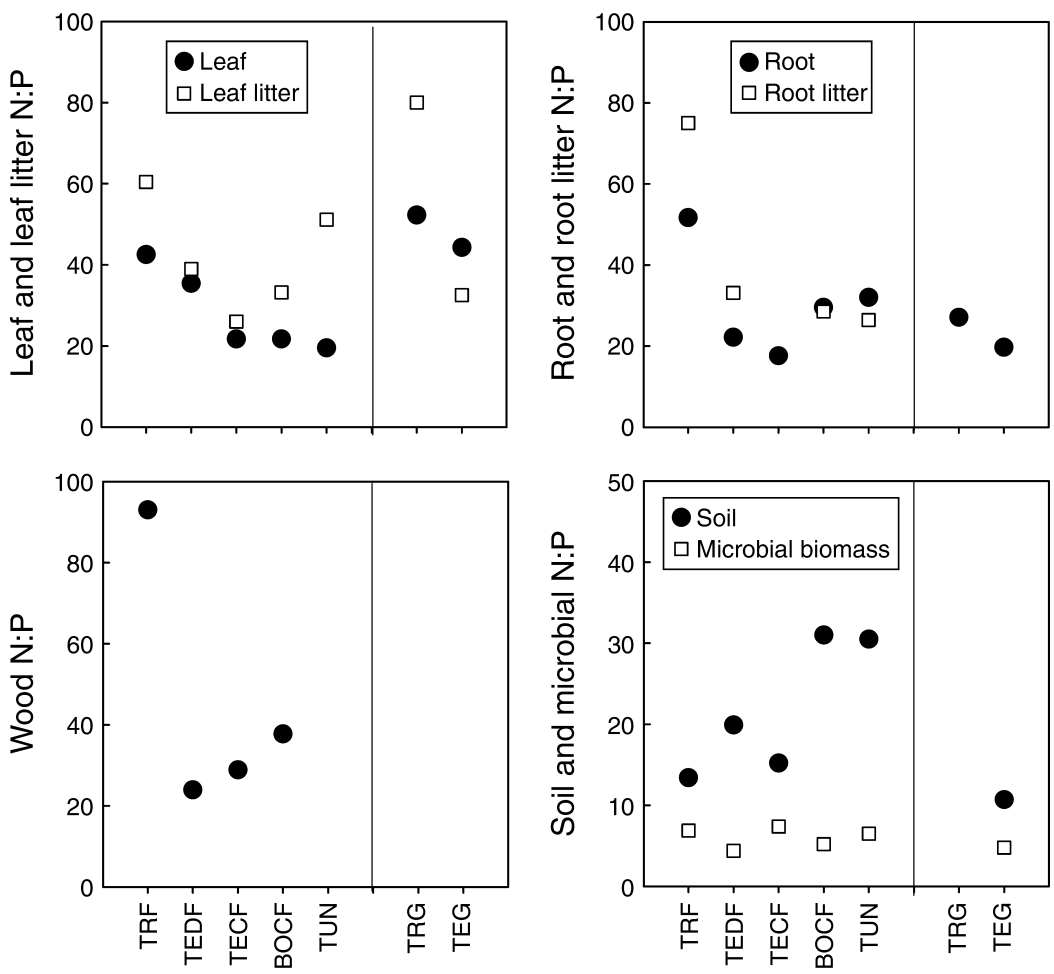

FIG. 1. Changes in ecosystem N:P stoichiometry across major biomes. The following biomes were targeted: tropical rain forests (TRF), temperate deciduous forests (TEDF), temperate coniferous forests (TECF), boreal coniferous forests (BOCF), tundra (TUN), tropical/ $\mathrm{C}_{4}$ grasslands (TRG), and temperate/ $\mathrm{C}_{3}$ grasslands (TEG). Vertical lines in each panel separate grassland biomes from the other biomes. All ratios are molar (atomic) ratios, and mass-based ratios were transformed to atomic ratios by dividing by the respective atomic masses. Data were compiled from the following sources: leaves (McGroddy et al. 2004, Reich and Oleksyn 2004, Wang et al. 2010), leaf litter (McGroddy et al. 2004, Yuan and Chen 2009, Brovkin et al. 2012), living fine roots (Gordon and Jackson 2000, Yuan et al. 2011), dead fine roots (Yuan et al. 2011), wood (Harmon et al. 1986, Martinelli et al. 2000, Weedon et al. 2009, Manzoni et al. 2010, Thomas and Martin 2012), soil organic matter (Xu et al. 2013), and soil microbial biomass (Xu et al. 2013). Most leaf stoichiometric ratios were taken from Wang et al. (2010); only those for TECF were obtained from McGroddy et al. (2004). Leaf litter ratios were mainly compiled from Yuan and Chen (2009); for TRG and TECF, they were taken from McGroddy et al. (2004) and Brovkin et al. (2012). Live-root stoichiometry was taken from root N, P, and N:P ratios (Fig. 2) and the mean C content (44.7\%) in Yuan et al. (2011). Live-root stoichiometry of TEDF, TECF, and BOCF was averaged from data by Gordon and Jackson (2000). Dead-root N:P was estimated from mean latitudes of major biomes and the power function in Fig. 1 $\left(\mathrm{N}: \mathrm{P}=66.6 \times\right.$ latitude $\left.^{-0.42}\right)$ of Yuan et al. (2011). No data were provided for C:N and C:P. Wood stoichiometry was taken as an average from data on TRF (Martinelli et al. 2000), TECF and TEDF (Harmon et al. 1986, Martinelli et al. 2000), and BOCF (Manzoni et al. 2010).

Fig. A1 for C:N and Fig. A2 for C:P). Moreover, plant $\mathrm{N}: \mathrm{P}$ ratios and the corresponding plant-litter $\mathrm{N}: \mathrm{P}$ ratios can vary strongly by several factors that affect the resorption process during leaf senescence (Aerts 1997b, Silla and Escudero 2006, Richardson et al. 2008, Reed et al. 2012, Mulder et al. 2013b) and that thereafter control the final litter stoichiometry, thus affecting its decomposability, soil trophic webs, and nutrient cycling (Zhang et al. 2008, Schneider et al. 2012, Schreeg et al. 2013).

\section{Soil and climate gradients and the explanation of global} trends in leaf stoichiometries

This relationship between latitude and leaf N:P ratio may be related to the substrate age hypothesis $(\mathrm{SAH}$; Walker and Syers 1976), which claims that old tropical soils have a low capacity to release $\mathrm{P}$ from parental material (Table 1; Vitousek et al. 2010). In contrast, N- containing compounds available to plants are nearly absent from igneous and metamorphic rocks (Vitousek et al. 2010), and most terrestrial ecosystems are largely devoid of $\mathrm{N}$ as they begin their development (Walker and Syers 1976, Holloway and Dahlgren 2002). Nitrogen, though, accumulates over time by biological $\mathrm{N}$ fixation, when $\mathrm{N}$ fixers dominate in early stages of soil development, and/or by $\mathrm{N}$ deposition or biological $\mathrm{N}$ fixation from dispersed sources (Vitousek et al. 2010). The SAH therefore predicts young soils to be $\mathrm{N}$ limited, and as soils age, continued weathering, cation and $\mathrm{P}$ losses, and $\mathrm{N}$ inputs cause them to become $\mathrm{N}$ rich but $\mathrm{P}$ poor. This hypothesis is supported by several studies on nutrient cycling, soil and plant chemistry, and soil chronosequences from young to old soils (Richardson et al. 2005). They further confirm a general trend of increasing $\mathrm{P}$ limitation toward areas with a tropical climate (Reich and Oleksyn 2004, Elser et al. 2007, 
TABLE 1. Brief explanation of commonly used terms in the framework of ecological stoichiometry.

\begin{tabular}{|c|c|}
\hline Concept & Definition \\
\hline Ecological stoichiometry (EST) & $\begin{array}{l}\text { Balance of multiple chemical substances in ecological interactions and processes, } \\
\text { or the study of this balance. Also sometimes refers to the balance of energy and } \\
\text { materials (Sterner and Elser 2002). }\end{array}$ \\
\hline Redfield ratio & $\begin{array}{l}\text { Well-constrained molar ratio of C:N:P in planktonic biomass of } 160: 16: 1 \text {; has } \\
\text { advanced the knowledge of biological processes and cycling in marine } \\
\text { ecosystems (Redfield 1958). }\end{array}$ \\
\hline Substrate age hypothesis (SAH) & $\begin{array}{l}\text { Younger soils at higher latitudes, rejuvenated by cyclic glaciations, have a higher } \\
\text { capacity to release P from parental materials than do older tropical soils whose } \\
\text { surface parental materials have long been leached and have consequently } \\
\text { become depleted in P (Walker and Syers 1976, Vitousek et al. 2010). }\end{array}$ \\
\hline Growth rate hypothesis (GRH) & $\begin{array}{l}\text { Elevated demands for increased allocation to P-rich ribosomal RNA under rapid } \\
\text { growth drives variation in the P content (and thus C:P and N:P ratios) of many } \\
\text { biota (Elser et al. 2003). }\end{array}$ \\
\hline Nutrient use efficiency & $\begin{array}{l}\text { Amount of production per unit nutrient used (Bridgham et al. 1995). Microbes } \\
\text { excrete nutrients that are present in excess in their substrates compared to their } \\
\text { biomass composition by adjusting their element use efficiencies. }\end{array}$ \\
\hline Homeostasis & $\begin{array}{l}\text { Results in narrowing of variation in chemical content in an organism compared to } \\
\text { the resources it consumes (Sterner and Elser 2002). }\end{array}$ \\
\hline Consumer-driven nutrient recycling (CNR) & $\begin{array}{l}\text { Homeostatic organisms regulate their elemental composition by retaining elements } \\
\text { in which they are limited and releasing those in excess (Sterner and Elser 2002). }\end{array}$ \\
\hline Threshold elemental ratio (TER) & $\begin{array}{l}\text { Defines the transition of an ecological system from being controlled by energy } \\
\text { flow (C) to being controlled by limiting nutrient flow (N or P; e.g., Urabe and } \\
\text { Watanabe 1992, Anderson and Hessen 1995, Frost et al. 2006); sometimes also } \\
\text { referred to as "breakpoint ratio" (e.g., Townsend et al. 2007). }\end{array}$ \\
\hline Resource allocation theory & $\begin{array}{l}\text { Enzyme production should increase when simple nutrients are scarce and complex } \\
\text { nutrients are abundant (Allison and Vitousek 2005). }\end{array}$ \\
\hline Overflow metabolism & $\begin{array}{l}\text { Microbial respiration of C in excess of metabolic requirements (Russell and Cook } \\
\text { 1995, Schimel and Weintraub 2003). }\end{array}$ \\
\hline
\end{tabular}

Note: All element ratios presented in this review are molar (atomic) rather than mass-based ratios.

Sardans et al. 2012b). Hence, the overall results suggest that P-rich bedrock and optimal climatic conditions for growth favor high leaf $\mathrm{N}$ and $\mathrm{P}$ concentrations (low $\mathrm{C}: \mathrm{N}$ and $\mathrm{C}: \mathrm{P}$ ratios) with low $\mathrm{N}: \mathrm{P}$ ratios.

\section{Ecological lifestyles and the explanation of global trends in leaf stoichiometries}

Not only bedrock and climate influence leaf stoichiometries; plant species with different ecological lifestyles have different $\mathrm{N}$ and $\mathrm{P}$ concentrations and $\mathrm{N}: \mathrm{P}$ ratios, and plants with higher growth rates typically have higher leaf $\mathrm{N}$ and $\mathrm{P}$ concentrations (lower $\mathrm{C}: \mathrm{N}$ and $\mathrm{C}: \mathrm{P}$ ratios) and lower leaf N:P ratios. These trends support the growth rate hypothesis (GRH; Table 1), which claims a relationship between growth rates and elevated demands for $\mathrm{P}$ for the synthesis of P-rich ribosomal RNA (Elser et al. 2000, Karpinets et al. 2006), the latter causing cytoplasmic N:P ratios to decline.

Globally, N:P ratios correlate negatively with growth rates (Sardans et al. 2012b). This is frequently observed when comparing plant species of different growth rates (Sterner and Elser 2002). Even though foliar N:P ratios tend to be higher toward tropical areas in a trend determined strongly by soil age, foliar N:P ratios are variable within each biome. This reflects variations in soil and topography, phylogenetic community composition, climatic conditions, and the ecological strategies and growth-rate capacities of the species. Within species, there is also a stoichiometric flexibility that has been related to species' lifestyles.
The differences in the concentrations and ratios of the elements as expressions of stoichiometric flexibility are greater (less homeostatic) in fast-growing species, with higher $\mathrm{N}$ and $\mathrm{P}$ concentrations and lower $\mathrm{C}: \mathrm{N}, \mathrm{C}: \mathrm{P}$, and $\mathrm{N}: \mathrm{P}$ ratios than in slow-growing species ( $\mathrm{Yu}$ et al. 2011). Aerts (1996) observed that the plant groups with less capacity to modify their resorption efficiency (plasticity) as a function of soil nutrient availability were evergreen shrubs and trees, the most slow-growing species.

Complementary hypotheses related to the GRH have been proposed to explain increases in plant nitrogen $(\mathrm{N})$ and phosphorus (P) concentrations with latitude: temperature-driven variations in growth rate, where greater growth rates (requiring greater nutrient levels) are needed to complete growth and reproduction within shorter growing seasons in temperate than tropical climates (Kerkhoff et al. 2005, Kerkhoff and Enquist 2006, Lovelock et al. 2007). Supporting this, a recent meta-analysis with a 6800-record database reveals that mean photosynthetic tissue $\mathrm{N}$ and $\mathrm{P}$ increase $(\mathrm{C}: \mathrm{N}$ and $\mathrm{C}: \mathrm{P}$ decrease) with latitude in aquatic and terrestrial ecosystems, but $\mathrm{P}$ increases more rapidly, causing $\mathrm{N}: \mathrm{P}$ to decline (Borer et al. 2013). This effect would be related to the decrease in growing-season length that makes photosynthetic tissues with high $\mathrm{N}$ and $\mathrm{P}$ concentrations and lower $\mathrm{N}: \mathrm{P}$ ratios more important for sustaining rapid production and growth to take advantage of short favorable growth periods for biomass production (Borer et al. 2013). Most meta-analyses support the conclusion that leaf $\mathrm{N}$ and $\mathrm{P}$ increase from the tropics to the cooler 


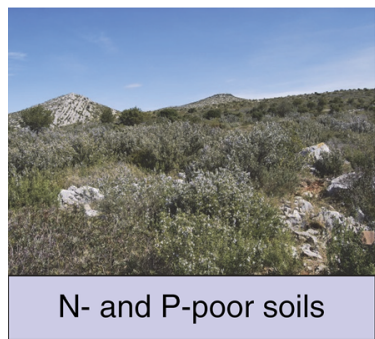

High resorption efficiency $\rightarrow$

$\downarrow N$ and $\downarrow P$ litter concentrations

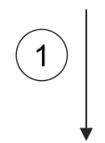

Low resorption efficiency $\rightarrow$

$\uparrow \mathrm{N}$ and $\uparrow \mathrm{P}$ litter concentrations

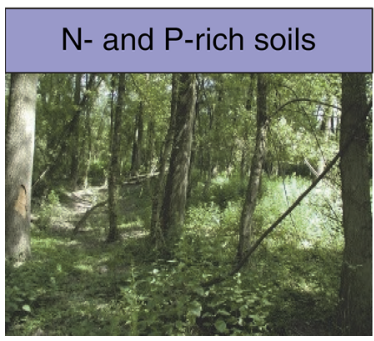

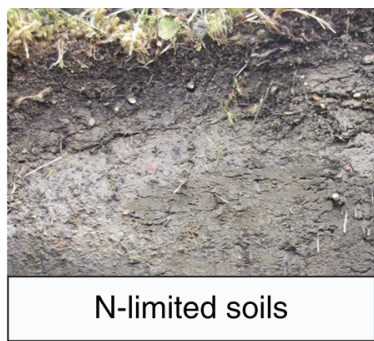

$\downarrow$ Leaf $\mathrm{N}: \mathrm{P} \rightarrow \uparrow \mathrm{N}: \mathrm{P}$ resorption

$\rightarrow \downarrow \downarrow$ litter $\mathrm{N}: \mathrm{P}$

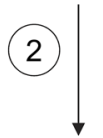

$\uparrow$ Leaf $\mathrm{N}: \mathrm{P} \rightarrow \downarrow \mathrm{N}: \mathrm{P}$ resorption $\rightarrow \uparrow \uparrow$ litter $\mathrm{N}: \mathrm{P}$

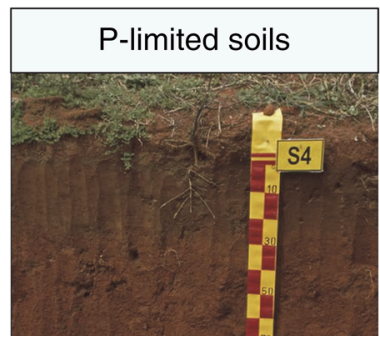

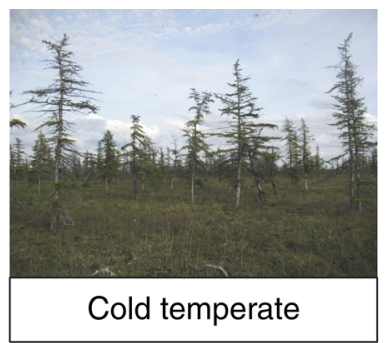

$\mathrm{N}$-limited soils

$\downarrow$ Leaf $\mathrm{N}: \mathrm{P} \rightarrow \uparrow \mathrm{N}: \mathrm{P}$ resorption

$\rightarrow \downarrow \downarrow$ litter N:P

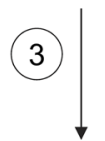

P-limited soils

$\uparrow$ Leaf N:P $\rightarrow \downarrow \downarrow N: P$ resorption

$\rightarrow \uparrow \uparrow \uparrow$ litter N:P

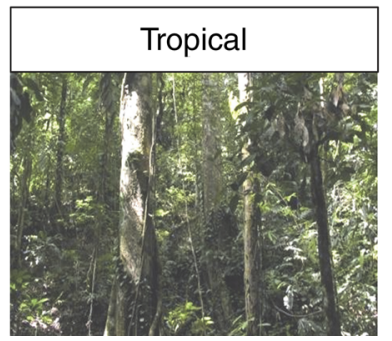

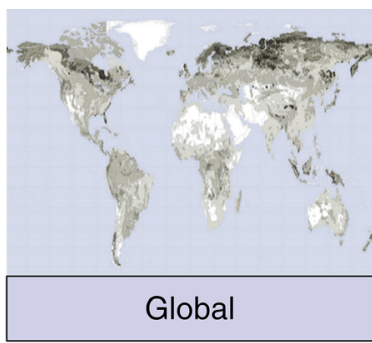

P-resorption efficiency

is globally higher than

N-resorption efficiency

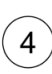

Average leaf $\mathrm{N}: \mathrm{P}$ ratio $=28: 1$

Average litter $N: P$ ratio $=45: 1$

FIG. 2. Global trends and mechanisms of changes in N:P ratios from leaves to leaf litter. Up arrows indicate increases, down arrows indicate decreases, and number of arrows indicates magnitude of change. Numbers correspond to trends listed in How do global gradients in climate and edaphic conditions affect plant and litter stoichiometry and decomposability?: Factors determining the differences in $N$ and $P$ concentrations and $C: N: P$ ratios between leaves and leaf litter. Photo credits (left to right, top to bottom): Josep Peñuelas, Andreas Richter, Jörg Schnecker, Sophie Zechmeister-Boltenstern, Martin Gerzabek, Wolfgang Wanek, Sophie Zechmeister-Boltenstern.

and drier mid-latitudes, and then plateau or decrease at high latitudes because of both the climate-related plant physiological stoichiometry and the biogeographical gradients in the frame of soil substrate age (Reich and Oleksyn 2004).

\section{Factors determining the differences in $N$ and $P$} concentrations and $C: N: P$ ratios between leaves and leaf litter

The key process that can generate differences between leaf and litter $\mathrm{N}$ and $\mathrm{P}$ concentrations and $\mathrm{C}: \mathrm{N}: \mathrm{P}$ ratios among and also within plant species is the leaf resorption efficiency (the percentage of leaf nutrients resorbed from leaves before leaf fall). Four general trends can be concluded from the literature when comparing the $\mathrm{N}$ and $\mathrm{P}$ concentrations and $\mathrm{N}: \mathrm{P}$ ratios of leaves to those of leaf litter (Fig. 2). First, a greater fraction of foliar $\mathrm{N}$ and $\mathrm{P}$ are resorbed in nutrient-poor soil-plant systems (Aerts 1996, Richardson et al. 2005, Silla and Escudero 2006, Li et al. 2012, Lu et al. 2012).
Second, N:P resorption ratios generally increase when the soil is $\mathrm{N}$ limited and generally decrease when the soil is P limited (van Heerwaarden et al. 2003, Zotz 2004). Third, foliar N:P resorption ratios on a global scale tend to increase with latitude and decrease with MAP and MAT, leading to a global trend to produce litter with very high $\mathrm{N}: \mathrm{P}$ ratios toward the tropics (McGroddy et al. 2004, Reed et al. 2012; Fig. 1). Soils consequently tend to develop higher N:P ratios over time (Hedin et al. 2003). This third trend is related to the $\mathrm{SAH}$, in the sense that, in general, as $\mathrm{P}$ becomes more limiting toward the tropics, plants decrease N:P resorption ratios. Fourth, despite the previous trends, $\mathrm{P}$ tends to be resorbed more than $\mathrm{N}$ on a global scale (Fig. 3), and this difference tends to be even higher in nutrient-rich sites, favoring leaves with lower N:P ratios and litter with higher N:P ratios (Mulder et al. 2013a).

The three first trends are related to the fact that plant species growing on soils with low nutrient availabilities have higher $\mathrm{N}$ and $\mathrm{P}$ resorption efficiencies than do 

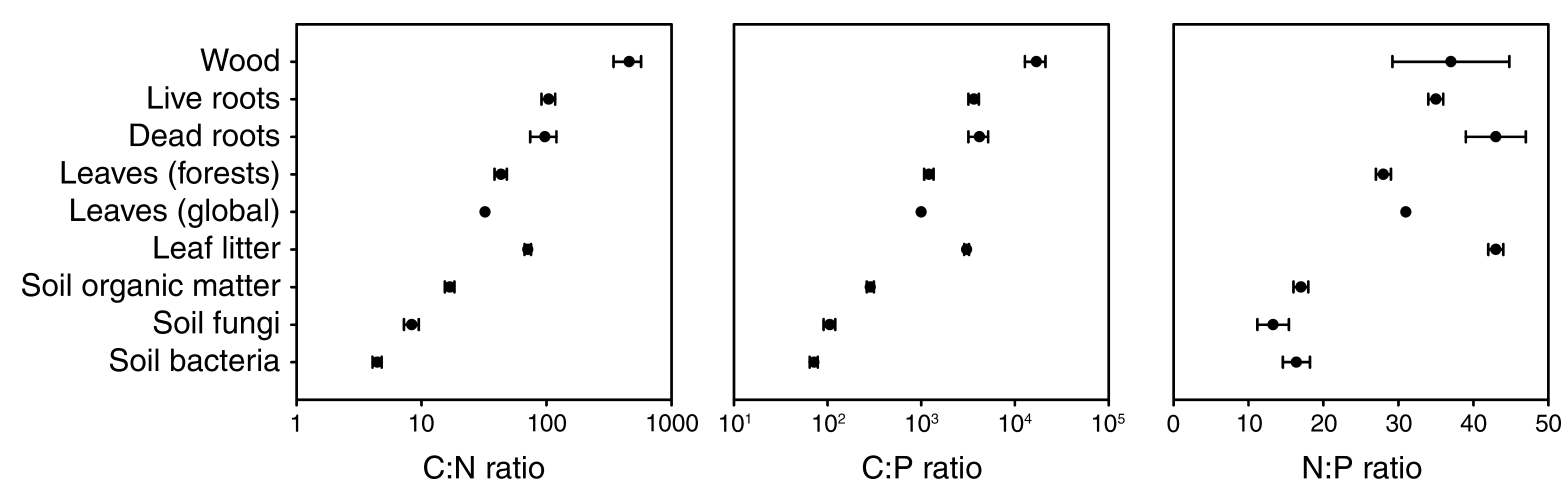

FIG. 3. Changes in global C:N:P ratios from live to dead plant materials, and convergence of C:N:P ratios from detrital pools toward soil organic matter and soil microbes. Data on global atomic C:N:P ratios were compiled or calculated from the following sources: wood (Harmon et al. 1986, Martinelli et al. 2000, Weedon et al. 2009), live and dead roots (Yuan et al. 2011), forest leaves (McGroddy et al. 2004), global leaves (Kattge et al. 2011), leaf litter (Yuan and Chen 2009), soil organic matter and soil microbial biomass (Xu et al. 2013), and fungi and bacteria (Mouginot et al. 2014a). Error bars show standard deviation.

species growing in richer soils (Aber and Melillo 1980, Aerts 1996, Côté et al. 2002, Martínez-Sánchez 2005, Richardson et al. 2005, Silla and Escudero 2006, Li et al. 2012, Lu et al. 2012), an effect related to a higher plant nutrient use efficiency, a longer nutrient mean residence time in plant biomass, and generally a more conservative use of nutrients when scarce (Aerts 1997b, Silla and Escudero 2006; Fig. 2). Plants growing in association with mycorrhizae and therefore having higher nutrient uptake rates resorb less $\mathrm{N}$ and $\mathrm{P}$ (Chuyong et al. 2000). Also, plants growing in dry areas resorb more $\mathrm{N}$ and $\mathrm{P}$ than do plants growing in wet areas (Sardans and Peñuelas 2013). Soils already low in nutrients thus receive even fewer nutrients from the litter (Kitayama et al. 2004, Kobe et al. 2005, Han et al. 2013), enhancing the recycling and nutrient use efficiency of plants with further feedback consequences on litter decomposition (Aerts and Chapin 2000). The N:P resorption ratio increases in N-limited soils, and the opposite occurs in P-limited soils (van Heerwaarden et al. 2003, Zotz 2004). By increasing P resorption, plants in P-limited soils thus produce litter with high N:P ratios, suggesting a limiting role of $\mathrm{P}$ for communities of soil-dwelling decomposers. The opposite occurs in N-limited soils (Fig. 2). Regardless, the differences in leaf and litter $\mathrm{N}$ and $\mathrm{P}$ concentrations and resorption efficiencies observed along soil $\mathrm{N}$ and $\mathrm{P}$ availability gradients are driven both by species-specific differences and also by the plasticity of individual species (Richardson et al. 2005).

The fourth trend indicates certain general asymmetric behaviors in $\mathrm{N}$ vs. $\mathrm{P}$ resorption and is consistent with most global meta-analyses that indicate broader ranges for $\mathrm{P}$ than for $\mathrm{N}$ resorption efficiencies (Mao et al. 2011, Vergutz et al. 2012). This trend is further corroborated by most experimental and observational studies (Kozovits et al. 2007, Hättenschwiler et al. 2008), despite the large variability of the results (Reed et al. 2012, Vergutz et al. 2012; Fig. 2). These meta-analyses observed that the proportional concentration of $\mathrm{C}$ and $\mathrm{N}$ relative to $\mathrm{P}$ is higher in litter than in leaves, 3007:45:1 and 1212:28:1, respectively (McGroddy et al. 2004), indicating a generally higher resorption efficiency of $\mathrm{P}$ than of $\mathrm{N}$. At least two circumstances seem to underlie this asymmetry. One is the necessity to retain $\mathrm{P}$ in the ecosystem because soils tend to develop $\mathrm{P}$ limitation with age. A high efficiency of $\mathrm{P}$ resorption is the main mechanism for the retention of $\mathrm{P}$ by plants in ecosystems on P-poor soils, as observed in several tropical and temperate forests (Hättenschwiler et al. 2008, Richardson et al. 2008). Analyses of global data sets (McGroddy et al. 2004, Reed et al. 2012) show that leaf litter tends to have higher N:P ratios toward tropical areas (Fig. 1), in accordance with the SAH and the increasing role of $\mathrm{P}$ limitation (Fig. 2). The leaf $\mathrm{N}$ resorption/P resorption efficiency ratio of forests is close to 0.6 in tropical ecosystems and rises to 1 in temperate ecosystems (Reed et al. 2012). The second cause of this asymmetry would be related to the GRH. In fact, optimum climatic conditions for plant growth frequently coincide with high foliar $\mathrm{N}$ and $\mathrm{P}$ concentrations and with low $\mathrm{N}: \mathrm{P}$ ratios in leaves (Reich and Oleksyn 2004, Kerkhoff et al. 2005, Yuan and Chen 2009, Sardans and Peñuelas 2013). In a meta-analysis of senescent leaves, Yuan and Chen (2009) observed that litter N concentrations increase from 10 to $15 \mathrm{mg} / \mathrm{g}$ and litter P concentrations decrease from 0.63 to $0.32 \mathrm{mg} / \mathrm{g}$ when MAP increases from 500 to $4000 \mathrm{~mm}$, confirming the decreasing $\mathrm{N}$ resorption/P resorption ratio with increasing MAP as observed in other meta-analyses (Reed et al. 2012).

\section{Convergence of C:N:P ratios of plant detrital inputs toward SOM and soil microbes during decomposition}

Beyond the focus on leaf litter, which is due to its importance as a source of detrital input, and due to the wealth of available data, other dead organic materials are also important as a source of energy and nutrients for decomposer communities (Freschet et al. 2013). For instance, coarse woody debris (CWD) represents an important localized input of plant detritus in forests worldwide. CWD input rates vary widely, but contribute 

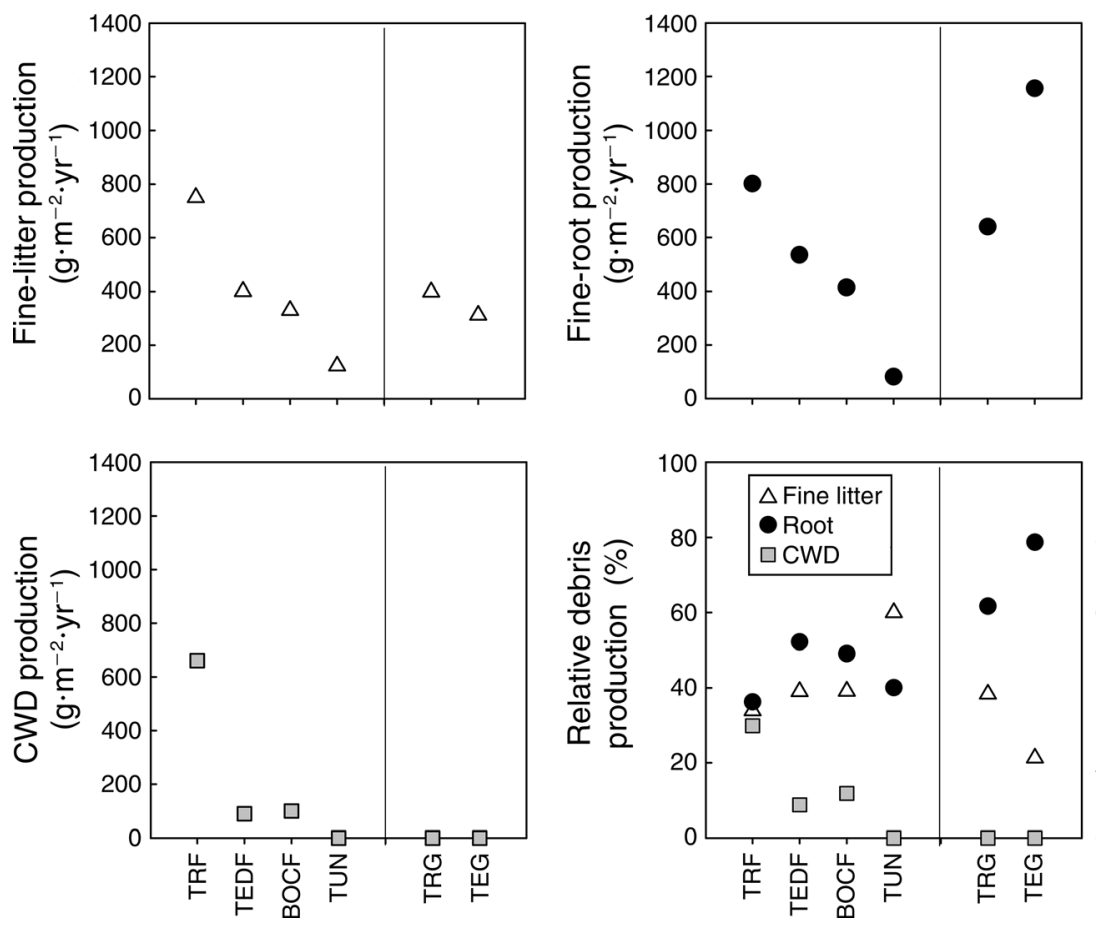

FIG. 4. Changes in plant debris production across major biomes (Fig. 1) and relative (percentage) contributions of fine-litter production, fine-root production, and coarse woody debris (CWD) production to total soil detritus inputs. Data for biome plant detritus production fluxes were compiled or calculated from the following sources: fine-litter production (Potter and Klooster 1997, Hui and Jackson 2006, Zhang et al. 2014), fine-root production (Hui and Jackson 2006, Finer et al. 2011 $a$, b), and CWD production (Potter and Klooster 1997, Palace et al. 2008). Fine-litter and fine-root production fluxes in TUN were calculated from the single studies (Chapin et al. 1988, Sullivan et al. 2007, 2008, Campioli et al. 2009, Sloan et al. 2013). Fine-root production in mature terrestrial ecosystems was assumed to be equal to root death and therefore with annual input of dead roots, with no resulting accrual in root biomass.

between $10 \%$ (temperate forests) and 30\% (tropical forests) to total plant detritus inputs to soil (Fig. 4). Compared to leaf litter (C:N:P of 3055:43:1) CWD has much higher $\mathrm{C}: \mathrm{N}: \mathrm{P}$ ratios (14 103:40:1) and markedly lower N and P concentrations (Harmon et al. 1986, Martinelli et al. 2000, Weedon et al. 2009) but similar $\mathrm{N}: \mathrm{P}$ ratios (43:1 vs. 40:1, Fig. 3). Tropical wood has higher N:P ratios than temperate and boreal wood (Fig. 1 ), and therefore follows the same large-scale latitudinal pattern as leaf litter, conforming to the SAH (Table 1).

Fine-root production and turnover also represent a quantitatively highly important input of plant detritus to soils. Decomposing fine roots are a key energy source to soil microbes and a major pathway of nutrient flux in terrestrial ecosystems (Yuan and Chen 2010). Globally, fine-root production increases from the arctic toward the tropical biome, and contributes between $40 \%$ and $80 \%$ of total detrital soil inputs (Fig. 4). Root litter has high C:N:P ratios (4184:43:1; Fig. 3), with N:P ratios similar to leaf litter and CWD. Due to the limited data on root litter stoichiometry, it remains unclear if systematic differences exist between ecosystems and biomes, but a trend of increasing dead-root N:P ratios toward the tropics has been reported (Gordon and Jackson 2000, Yuan et al. 2011). On the other hand, N:P ratios of living fine-root biomass clearly differed between biomes, declining exponentially with latitude (Fig. 1), which again conforms to the SAH (Yuan et al. 2011). It has been a longstanding debate whether $C$ and nutrient resorption occurs during fine-root senescence (Nambiar 1987). Only recently, mean root N (27\%) and $\mathrm{P}(57 \%)$ resorption was demonstrated in tundra ecosystems (Freschet et al. 2010), leading to a weak increase in root-litter N:P ratios relative to living fine roots (Yuan et al. 2011; Fig. 3). However, it seems that root resorption efficiencies are much lower compared to those of leaves (Freschet et al. 2010).

In contrast to the large observed differences in $\mathrm{C}: \mathrm{N}$ and C:P ratios between plant detritus pools, N:P ratios of these materials are relatively similar globally, ranging between 40:1 and 43:1 (Fig. 3). In addition, on a broad scale, $\mathrm{N}: \mathrm{P}$ ratios are highly similar in resource-acquiring plant biomass pools (i.e., between leaves and living fine roots) as well as in their detritus pools (i.e., between leaf and root litter). This indicates a common functional nutrient stoichiometry of the live plant tissues (Yuan et al. 2011), and similarities in above- and belowground nutrient resorption processes.

Great differences have been observed when comparing C:N:P ratios of plant detritus, SOM, and soil 
microbial biomass (Fig. 3). Analyzing a data set of 186 observations, Cleveland and Liptzin (2007) observed atomic C:N:P ratios of 186:13:1 in soils and of 60:7:1 in soil microbial biomass. More recently, analyzing a data set of 3422 data points from around the world, Xu et al. (2013) reported average C:N:P ratios of 287:17:1 and 42:6:1 for soil and soil microbial biomass, respectively (Fig. 3). These global data analyses therefore suggest the following patterns: (1) The losses of $\mathrm{N}$ must be much higher than the losses of $\mathrm{P}$ (from an N:P ratio of $\sim 40$ in litter to 6-7 in microbes; Fig. 3) during detritus decomposition and SOM formation, and that globally, terrestrial ecosystems are adapted to retain more $\mathrm{P}$ than $\mathrm{N}$. The fast turnover of microbes compared to plant tissue may be related to their high $\mathrm{N}$ and $\mathrm{P}$ concentrations (low C:N and C:P ratios) and low N:P ratios, suggesting that microbial biogeochemical processes will be one of the causes of the lower N:P ratios observed in soils compared to plant detritus, and thereby contribute to retaining proportionally more $\mathrm{P}$ than $\mathrm{N}$ in soils. (2) During organic matter decomposition, losses of $\mathrm{C}$ are much greater than those of $\mathrm{N}$ or $\mathrm{P}$. This causes the $\mathrm{C}: \mathrm{N}$ and $\mathrm{C}: \mathrm{P}$ ratios of decomposing plant detritus to decline and converge toward SOM and soil microbial biomass (Fig. 3). As outlined in What are the effects of variable resource stoichiometry on microbial community structure and function?: Mechanisms regulating microbial carbon and nutrient cycling in response to resource stoichiometry, microbial C use efficiency (CUE) is expected to be low in C-rich resources such as plant detritus, causing large respiratory losses of organic $\mathrm{C}$ while nutrients are retained with higher efficiencies (Mooshammer et al. $2014 a, b)$. In soils with low $\mathrm{C}$ : nutrient ratios, CUE is expected to be higher and microbes to become energy limited but less nutrient conservative. The convergence of detrital C:N:P toward SOM and soil microbes during decomposition (see patterns 1 and 2) is therefore based on microbial decomposition processes causing larger $\mathrm{C}$ than nutrient losses from decomposing organic matter (Manzoni et al. 2012). Moreover, the pattern is also reflected in the increasing contribution of microbial remains to decomposing organic matter and ultimately to SOM (Simpson et al. 2007, Miltner et al. 2012), and highlights the impact of microbial physiology on SOM formation and on its chemistry viz. stoichiometry. (3) The latitudinal trends in $(\mathrm{C}:) \mathrm{N}: \mathrm{P}$ ratios as found in plant biomass and plant detrital pools (Fig. 1; Appendix A: Figs. A1 and A2) are not reflected in SOM and soil microbial biomass (Xu et al. 2013). In contrast, soils show an inverse trend in (C:) N:P ratios from tropical forests toward tundra ecosystems, and neither the detritus nor the soil N:P trends are reflected in soil microbial biomass. Soil microbes are therefore largely, though not strictly, homeostatic in terms of $\mathrm{C}: \mathrm{N}: \mathrm{P}$ stoichiometry (Cleveland and Liptzin 2007, Sistla and Schimel 2012, Hartman and Richardson 2013, Xu et al. 2013, Li et al. 2014). In EST, homeostasis relates to the physiological regulation of organism biomass stoichi- ometry, where in strict homeostasis, variable resource stoichiometry has no effect on organism stoichiometry (Sterner and Elser 2002). Mechanisms of homeostatic regulation are discussed in What are the effects of variable resource stoichiometry on microbial community structure and function?: Mechanisms regulating microbial carbon and nutrient cycling in response to resource stoichiometry and by Mooshammer et al. (2014b). Despite microbes being largely homeostatic, the soil microbial biomass shows relative flexibility in its $\mathrm{C}: \mathrm{N}: \mathrm{P}$, and significant differences have been found between biomes and ecosystem types (Hartman and Richardson 2013, Xu et al. 2013, Li et al. 2014). The increase in soil $\mathrm{N}: \mathrm{P}$ ratios (and in $\mathrm{C}: \mathrm{N}$ and $\mathrm{C}: \mathrm{P}$ ) from low- to highlatitude ecosystems is paralleled by increases in surface SOM content (0-15 cm depth; Xu et al. 2013). Soil N:P increases from low- to high-humic soils (Appendix: Fig. A3), and therefore positively scales with SOM content (Hartman and Richardson 2013). As forest floor and organic soils are high in organic matter that is less microbially decomposed, they are also more closely related to plant detritus with high C:N, C:P, and N:P ratios compared to mineral soils with strongly decomposed organic materials that are stoichiometrically more closely related to microbial remains (Appendix: Fig. A3). The same trend, decreases in soil C:N:P with decreasing SOM content and increasing microbial processing of this organic matter, was also found with increasing soil depth (Tian et al. 2010). C:N:P ratios of detritus and SOM therefore closely reflect the degree of microbial decomposition of organic matter.

Synthesizing the latest outcomes of biogeochemical research, we conclude that microbes worldwide encounter different concentrations and stoichiometric ratios of $\mathrm{C}, \mathrm{N}$, and $\mathrm{P}$, depending on climate, soil type, and soil age. Global latitudinal gradients display higher N:P ratios of plant tissues and litter (but not in soils and soil microbes) toward the tropics, indicative of decreasing plant $\mathrm{P}$ availability at low latitudes. Microbially mediated decomposition of plant detritus causes $\mathrm{C}: \mathrm{N}: \mathrm{P}$ ratios to decline and converge toward SOM and ultimately microbial biomass. Changes in $\mathrm{C}: \mathrm{N}: \mathrm{P}$ ratios cause feedback effects on the decomposition process and on nutrient recycling, but is it possible to predict the sequel for the microbial community, their physiology, and competitive strategies?

\section{What Are the Effects of Variable Resource Stoichiometry on Microbial Community Structure AND FunCtion? \\ Stoichiometry and the decomposition rates of different plant materials}

Microbial decomposition of plant detritus results in the breakdown and respiratory use of organic $\mathrm{C}$ as well as in the mineralization and recycling of nutrients. The nutrient status of ecosystems strongly affects nutrient concentrations and the stoichiometry of plant detritus. To what extent do these stoichiometric differences feed 
back on decomposition rate and hence on nutrient recycling? Can we detect major differences in decomposition rate between different types of plant detritus?

Leaf litter decomposes much faster than wood, with a global mean $k$ value of $0.58 \mathrm{~g} \cdot \mathrm{g}^{-1} \cdot \mathrm{yr}^{-1}$ for leaf litter (Zhang et al. 2008) and $0.05-0.1 \mathrm{~g} \cdot \mathrm{g}^{-1} \cdot \mathrm{yr}^{-1}$ for dead wood (Weedon et al. 2009). Globally, root litter decomposes slightly faster $\left(0.83 \mathrm{~g} \cdot \mathrm{g}^{-1} \cdot \mathrm{yr}^{-1}\right.$; Silver and Miya 2001) than leaf litter, which is not necessarily the case when root and leaf litter decomposition are studied at the same site, e.g., Freschet et al. (2012). These tissuespecific differences in decomposition can be caused by differences in a wide array of chemical and structural traits, or different environmental conditions under which the studies were undertaken. More generally, decomposition of plant detritus is driven by multiple factors, of which soils, climate, decomposer communities, and litter quality are the most important (Berg and McClaugherty 2003). Litter quality is a broad term including chemical variables such as $\mathrm{C}$ chemistry (lignin and carbohydrate content, secondary compounds), element contents $(\mathrm{N}, \mathrm{P}, \mathrm{Ca}, \mathrm{K}$, etc.) and their ratios $(C: N, C: P, N: P$, lignin : N), and structural variables such as tissue density and surface: volume ratio.

Climate has been implicated as the most important direct control on litter decomposition, with variable results from multi-site experiments where litter of the same species was decomposed; in tropical sites, MAP was most important (Powers et al. 2009), while in temperate and boreal sites, MAT played the key role (Trofymow et al. 2002). However, two recent metaanalyses clearly showed that climate is less rate limiting compared to litter quality. The meta-analysis by Zhang et al. (2008) demonstrated that litter quality explained $73 \%$ of the variability in decomposition rate across plant species and types of plant tissues while MAT and MAP accounted for a maximum of $30 \%$, some part of which was caused by collinearity between climate and litterquality parameters. Similarly, Cornwell et al. (2008) cite a sixfold range in decomposition rates of litter from the same species decomposing in very different climate conditions (Parton et al. 2007), but found an 18-fold range in decomposition rates of leaf litter of different species decomposing at the same site.

Which litter trait is most important in controlling decomposition globally? Structural parameters have been shown to be important determinants of wood decomposition, such as the diameter of the decomposing wood piece (analogous to surface area: volume ratio) and tissue density (wood density; van Geffen et al. 2010, Pietsch et al. 2014), and leaf litter decomposition was shown to be negatively affected by leaf mass per area (Cornwell et al. 2008, Pietsch et al. 2014). Low surface area : volume ratios and high tissue densities decrease the accessibility to the decomposer community and their extracellular enzymes, and increase recalcitrance.

The relative importance of $\mathrm{C}$ chemistry, element contents, and element stoichiometry as determinants of litter decomposition varies from study to study, depending on decomposition environment and tissue type. Carbon chemistry, such as lignin and tannin content, lignin : carbohydrate, and lignin: $\mathrm{N}$ ratios, has been implicated as a major factor negatively affecting litter decomposition (Melillo et al. 1982, Hättenschwiler and Jorgensen 2010, Talbot and Treseder 2012). Litter element contents, particularly $\mathrm{N}$ and $\mathrm{P}$, strongly positively affect the decomposition rate of dead wood (Weedon et al. 2009), root litter (Silver and Miya 2001), and leaf litter (Cornwell et al. 2008). However, essential cations such as $\mathrm{Ca}, \mathrm{Mg}$, and $\mathrm{K}$ also exert strong positive controls on the decomposition of dead roots (Silver and Miya 2001) and across all types of plant detritus (Zhang et al. 2008), and therefore shall be included in a stoichiometric view of litter decomposition.

The importance of litter stoichiometry for decomposition has also been investigated across the full breadth of autotrophic detrital tissues, ranging from unicellular algae to trees; detrital $\mathrm{C}: \mathrm{N}$ and $\mathrm{C}: \mathrm{P}$ ratios were strongly negatively related to decomposition rates (Enríquez et al. 1993). In our data compilation of detrital C:N:P and decomposability across leaf litter, root litter, and CWD, we found a strong curvilinear response of litter decomposition rate to $\mathrm{C}: \mathrm{N}$ and $\mathrm{C}: \mathrm{P}$, but not to $\mathrm{N}: \mathrm{P}$ (Fig. 5). This indicates that decomposition of plant detritus is nutrient but not energy (C) limited, given the necessary investment of ( $\mathrm{C}$ and) $\mathrm{N}$ into extracellular enzymes by decomposer microorganisms and based on the high demand of microbial decomposers for $\mathrm{N}$ and $\mathrm{P}$ to build and maintain biomass. Moreover, decomposition nearly halts above $\mathrm{C}: \mathrm{N}$ ratios of 100 and $\mathrm{C}: \mathrm{P}$ ratios of 4000 , pointing to $\mathrm{C}$ : nutrient thresholds at which nutrient limitation outrivals any other environmental or chemical factor (Fig. 5). One emerging question is whether $\mathrm{C}: \mathrm{N}(\mathrm{C}: \mathrm{P})$ effects are really stoichiometric or only reflect the effect of $\mathrm{N}(\mathrm{P})$ on nutrient-limited litter decomposition where organic $\mathrm{C}$ is in excess and litter $\mathrm{C}$ concentrations are relatively invariable (40-50\%). Therefore litter $\mathrm{N}(\mathrm{P})$ content is strongly negatively related to litter $\mathrm{C}: \mathrm{N}(\mathrm{C}: \mathrm{P})$, and it is ambiguous whether nutrient contents or $\mathrm{C}$ : nutrient ratios are the primary agent affecting litter decomposition. In regression models testing for $\mathrm{N}(\mathrm{P})$ and $\mathrm{C}: \mathrm{N}(\mathrm{C}: \mathrm{P})$ effects, nutrient contents sometimes explain a larger fraction of variance in decomposition rate (Zhang et al. 2008), sometimes $\mathrm{C}$ : nutrient ratios are better explanatory variables (Silver and Miya 2001, Weedon et al. 2009). It is therefore likely that true $\mathrm{C}: \mathrm{N}$ and $\mathrm{C}: \mathrm{P}$ effects are smaller compared to direct nutrient effects on litter decomposition. The strong correlation between detritus $\mathrm{N}$ and $\mathrm{P}$ across a broad scale of plant tissues (Enríquez et al. 1993), and similar slopes of litter decomposition with litter $\mathrm{N}$ or litter $\mathrm{P}$ indicate that litter N:P does not vary much across different plant materials and environmental conditions, compared to $\mathrm{C}$ :nutrient ratios (see also Fig. 3). Accordingly, litter N:P may not significantly 


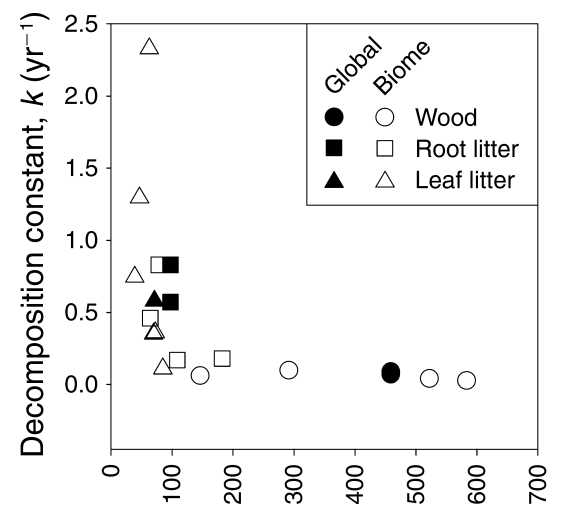

$\mathrm{C}: \mathrm{N}$ ratio

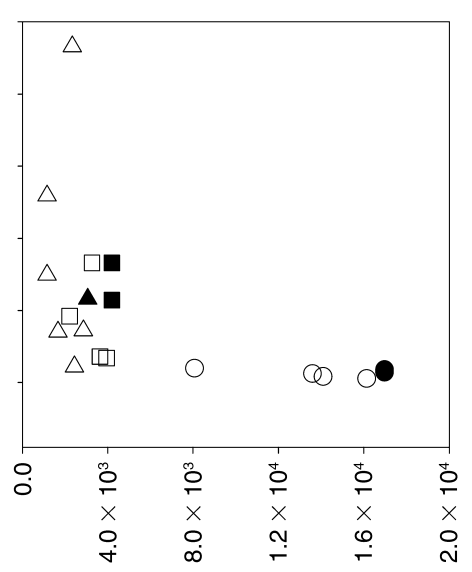

C:P ratio

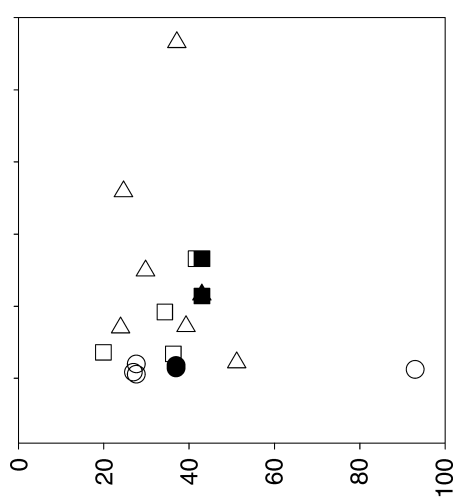

$\mathrm{N}: \mathrm{P}$ ratio

FIG. 5. Effects of C:N:P stoichiometry of plant detritus on its decomposition rate. Decomposition rate is given as decomposition constant $k\left(\mathrm{~g} \cdot \mathrm{g}^{-1} \cdot \mathrm{yr}^{-1}\right)$; stoichiometric ratios are molar. Circles represent wood, rectangles root litter, and triangles leaf litter data; solid symbols are global means and open symbols are biome means. Wood data are shown as global, tropical, temperate/boreal, angiosperm, and gymnosperm averages, root litter data as global, broadleaf, conifer, fine-, and coarse-root averages, and leaf litter data as global, tropical, temperate, broadleaf forest, coniferous forest, and tundra averages. Data were from the following sources: C:N:P stoichiometry (Harmon et al. 1986, Aerts 1997a, Martinelli et al. 2000, Silver and Miya 2001, Zhang et al. 2008, Yuan and Chen 2009, Kang et al. 2010, Yuan et al. 2011); decomposition (Harmon et al. 1986, Aerts 1997a, Silver and Miya 2001, Zhang et al. 2008, van Geffen et al. 2010).

affect decomposition rates (Enríquez et al. 1993) compared to $\mathrm{N}$ and $\mathrm{P}$ concentrations.

Structural and chemical parameters are often tightly related. For instance, for leaf litter, mass loss was negatively related to leaf mass per area, lignin content, and polysaccharide content, and positively related to litter $\mathrm{N}$ and $\mathrm{P}$ across 818 plant species (Cornwell et al. 2008). Moreover, this set of litter traits is highly coordinated in leaves (termed the leaf economics spectrum) and reflects the plant species' ecological strategy, i.e., being slow-growing, long-lived, and nutrient-conservative, or vice versa (Wright et al. 2004). The leaf economics spectrum therefore has a strong "influential afterlife, affecting the rate of decomposition" (Cornwell et al. 2008). Furthermore, decomposition rates of leaves, fine roots, and fine stems were recently demonstrated to be coordinated across species globally (Freschet et al. 2013). Similarly wood and leaf litter decomposability of $>300$ tree species was positively correlated and related to plant functional traits along the leaf and wood economics spectrum. The covariation of structural and chemical litter traits along a plant economics spectrum hinders the study of the importance of single traits, though plant mutants with altered cellulose or lignin content and lignin structure have helped investigate mechanisms and feedbacks of these traits on decomposition (Talbot and Treseder 2012). Also, comparative studies focusing on leaf litter from one plant species with similar structure and C chemistry but different $\mathrm{C}: \mathrm{N}: \mathrm{P}$ stoichiometries can overcome this handicap (Manzoni et al. 2010, Keiblinger et al. 2012). For instance, faster decomposition rates have been measured with lower leaf litter N:P ratios than with higher ones (Schneider et al. 2012). This shows that besides nutrient limitation of microbial decomposers of plant detritus, a certain relative proportion of nutrients is crucial for high decomposer activity, an activity expressed as enzyme and respiratory activities (Schneider et al. 2012).

We conclude that (1) litter chemistry outrivals environmental drivers of litter decomposition rates, (2) nutrient concentrations, specifically litter $\mathrm{N}$ and $\mathrm{P}$, have a strong positive effect on litter decomposition rates, which may exceed the effect of stoichiometry, i.e., litter $\mathrm{C}: \mathrm{N}: \mathrm{P}$ ratios, and that (3) globally, litter nutrient concentration, litter C quality (lignin content), and structural features covary, making individual controls on microbial communities and decomposition processes difficult to tease apart.

\section{Mechanisms regulating microbial carbon and nutrient cycling in response to resource stoichiometry}

Besides environmental factors, resource stoichiometry can limit microbial activity, thereby governing ecosystem-level C and nutrient flow (Sterner and Elser 2002). Given that microbial stoichiometry is the basis for the nutrient requirements of decomposer communities, the stoichiometric imbalance between resource and microbial biomass reflects a limitation of microbial activity by a particular nutrient. For example, heterotrophic microorganisms in plant litter are thought to be limited by $\mathrm{N}$ or $\mathrm{P}$, whereas microbial communities decomposing SOM are expected to be $\mathrm{C}$ limited, because (simplistically) the progressively lower C:N or C:P ratios from litter to organic soil, and further to mineral soil, correspond to a decreasing $\mathrm{C}$ availability in relation to 


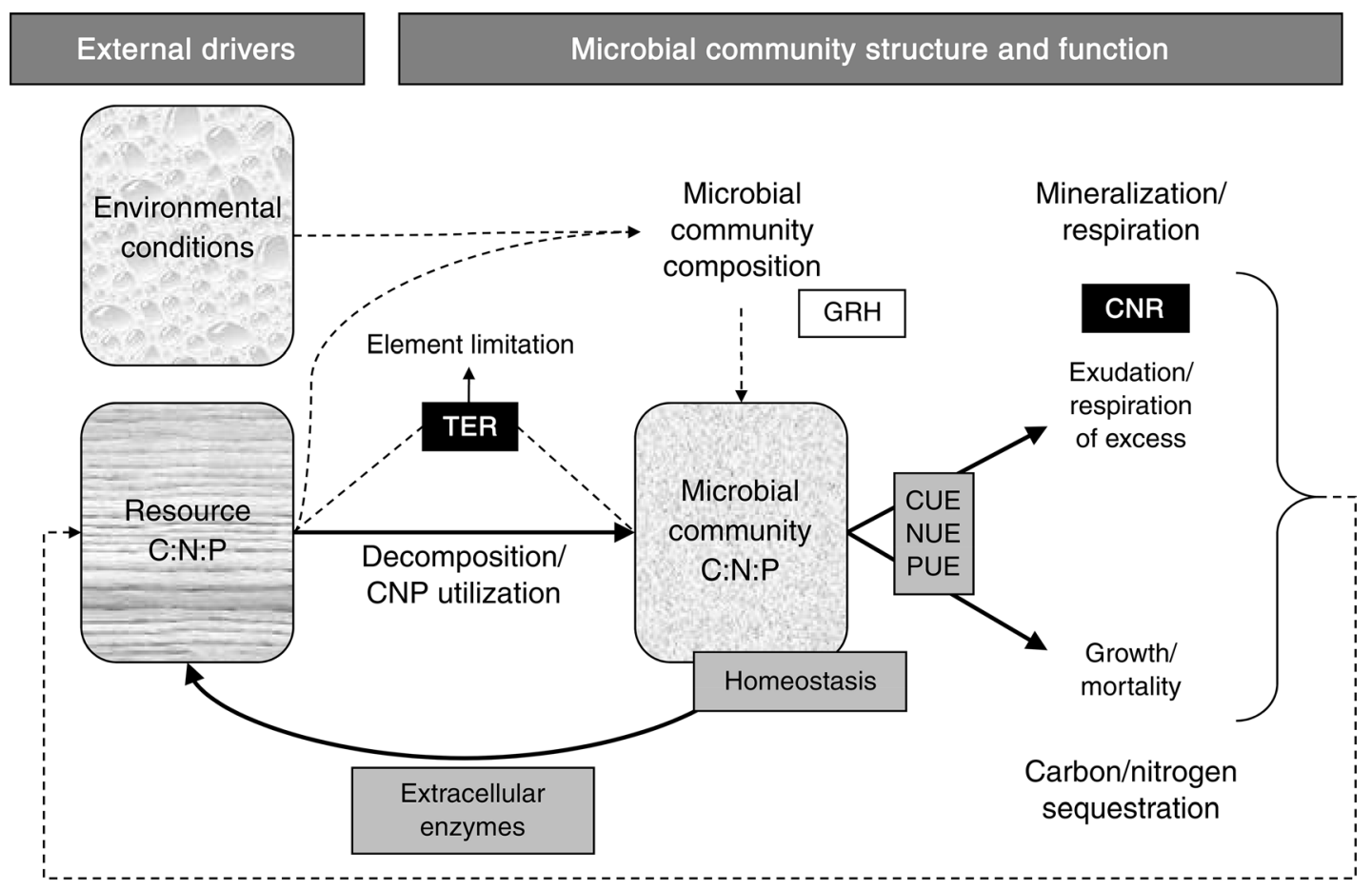

Feedback

FIG. 6. Proposed effects of resource stoichiometry and environment on microbial community structure and function. Major concepts of ecological stoichiometry and important microbial features are indicated: threshold element ratio (TER), consumerdriven nutrient recycling (CNR), growth rate hypothesis (GRH), homeostasis, extracellular enzymes, C use efficiency (CUE), N use efficiency (NUE), P use efficiency (PUE), mineralization and respiration, and growth. Solid lines indicate processes/fluxes, while dashed lines indicate influences/controls. Black boxes indicate central hypotheses of ecological stoichiometry related to microbial biogeochemical processes (TER and CNR), the open box indicates another important hypothesis not directly related (GRH), and gray boxes indicate parameters and processes underlying stoichiometric responses of microbial communities to elemental imbalances.

$\mathrm{N}$ and $\mathrm{P}$ (increasing $\mathrm{C}$ limitation). Such different elemental limitations for microbial growth have distinct implications for individual microbially mediated $\mathrm{C}$ and nutrient fluxes, leading to feedbacks on nutrient availability (Fig. 6). The most prominent examples are the release of excess $\mathrm{C}$ via overflow respiration under nutrient limitation (Tempest and Neijssel 1992) and the release of excess $\mathrm{N}$ as ammonium contributing to $\mathrm{N}$ mineralization flux under $\mathrm{C}$ (or another element than $\mathrm{N}$ ) limitation (Schimel and Weintraub 2003). A differential recycling of $\mathrm{C}$ and nutrients $(\mathrm{N}$ or $\mathrm{P}$ ) as a consequence of imbalance between resource stoichiometry and microbial nutrient demand results in disparate $\mathrm{C}$ : nutrient release ratios and is termed the consumer-driven nutrient recycling theory (CNR; Sterner 1990, Elser and Urabe 1999, Sterner and Elser 2002). The CNR theory proposes that the balance of the stoichiometry of resource and consumer and their element use efficiency, such as CUE, directly determines the ratios of nutrient recycling. A key assumption for CNR is that consumers are (strictly) homeostatic (Sterner and Elser 2002). Soil microbial communities exhibit a large degree of stoichiometric homeostasis, which they maintain by adjusting (1) their element use efficiency (to release elements in excess and optimize the use of limiting elements) and (2) their extracellular enzyme production (to mobilize resources to meet their elemental demand; Mooshammer et al. 2014b). These are the underlying mechanisms of the CNR theory (Fig. 6), and are discussed in the framework of the threshold elemental ratio (TER). The CNR theory is intimately linked to the TER that represents an indicator of relative nutrient limitation, providing a tool to understand constraints on microbial growth by different nutrient availabilities in the environment. TER is commonly integrated in decomposition models to predict microbial $\mathrm{C}$ and nutrient fluxes as a function of resource stoichiometry (e.g., Manzoni and Porporato 2009, Moorhead et al. 2012, Averill 2014).

TER is defined as the elemental $\mathrm{C}$ : nutrient ratio at which the control of microbial metabolism switches from energy (C) to nutrient ( $\mathrm{N}$ or P) supply (e.g., Urabe and Watanabe 1992, Anderson and Hessen 1995, Frost et al. 2006, Doi et al. 2010). Thus, a certain nutrient becomes limiting for growth when resource $\mathrm{C}$ : nutrient ratios are greater than TER. Because TER links microbial biomass stoichiometry and element use efficiencies, it may vary by the extent to which microbial homeostasis is maintained in relation to variations in 
external resource supply. In practice, TER can be estimated from the transition from net nutrient immobilization to net nutrient mineralization during organic matter decomposition, i.e., the critical C:N or C:P ratio (or TER $\mathrm{C}_{\mathrm{N}: \mathrm{N}}$ or TER $\mathrm{C:P}$ ). Usually, $\mathrm{TER}_{\mathrm{C}: \mathrm{N}}$ for terrestrial decomposers is thought to be relatively constant around a molar ratio of 23-47 (e.g., Berg and McClaugherty 2003, Moore et al. 2006, Parton et al. 2007). For forest floor organic matter, a critical C:P molar ratio of 1420 has been reported (Saggar et al. 1998). Plant litter, however, is almost always rich in C compared to nutrients and, thus, terrestrial litter decomposition is considered to be $\mathrm{N}$ or $\mathrm{P}$ limited rather than $\mathrm{C}$ limited. In the case that plant litter has a $\mathrm{C}: \mathrm{N}$ and $\mathrm{C}: \mathrm{P}$ ratio above the microbial TER $\mathrm{C}: \mathrm{N}_{\mathrm{N}}$ and $\mathrm{TER}_{\mathrm{C}: \mathrm{P}}$, respectively, we can adapt the TER concept to the transition from microbial $\mathrm{N}$ to $\mathrm{P}$ limitation. The TER $\mathrm{N}: \mathrm{P}$ or critical $\mathrm{N}: \mathrm{P}$ ratio for decomposition was proposed to range between a molar ratio of 20 and 33 (Aerts 1997a, Smith 2002). Notably, Güsewell and Freeman (2005) found that litter decomposition was always $\mathrm{P}$ limited for litter with molar N:P ratio above 49 , but could be $\mathrm{N}$ or $\mathrm{P}$ limited with lower $\mathrm{N}: \mathrm{P}$ ratios. Although litter decomposition is considered to be nutrient limited ( $\mathrm{N}$ or $\mathrm{P}$ ), it is often limited by low C quality (Ågren et al. 2001, Bridgham and Richardson 2003). The consequence of high recalcitrance of organic matter for TER $\mathrm{T}_{\mathrm{N}: \mathrm{P}}$ was illustrated by Sinsabaugh and Follstad Shah (2011) in the context of the GRH and their reinterpretation of the results of Güsewell and Gessner (2009). That study found that increasing the nutrient supply to the plant litter decomposers increased mass loss rates and shifted community composition, and thereby the TER $\mathrm{N}_{\mathrm{N}: \mathrm{P}}$ of microbial decomposers decreased from a molar ratio of 100 to 4 . According to the GRH, increasing resource supply promotes faster growth, which increases biomass $\mathrm{P}$ relative to $\mathrm{N}$ (Sterner and Elser 2002). The resulting higher $P$ demand then shifts the $\mathrm{TER}_{\mathrm{N}: \mathrm{P}}$ toward a lower N:P ratio. In turn, in plant litter with low $\mathrm{C}$ quality, a significant fraction of essential elements ( $\mathrm{N}$ in particular) are bound in recalcitrant molecules, reducing nutrient availability. As organic matter recalcitrance increases, nutrient supply effectively declines. Consistent with the GRH, microbial growth rates and biomass $\mathrm{P}$ decrease and consequently TER $\mathrm{N}_{\mathrm{N} P \mathrm{P}}$ increases due to lower microbial $\mathrm{P}$ demand. The TER $\mathrm{N}_{\mathrm{P}}$ thus is, among other factors, strongly dependent on plant species composition, which determines $\mathrm{C}$ quality, $\mathrm{N}: \mathrm{P}$ ratio, and initial $\mathrm{N}$ and $\mathrm{P}$ concentration.

The TER concept integrates the metabolic theory of ecology (MTE), which describes ecological organization in thermodynamic terms, and the EST, which describes ecological organization in terms of elemental resource availability (Sterner and Elser 2002, Brown et al. 2004, Allen and Gillooly 2009). Extracellular enzyme activities (EEA) represent an intersection of MTE and EST because enzyme expression is a product of cellular metabolism specifically regulated by environmental nutrient availability. The application of EEA through TER has become an emerging conceptual framework of ecoenzymatic stoichiometry (Sinsabaugh et al. 2008, 2009, Sinsabaugh and Follstad Shah 2011, 2012). By using the activities of $\beta$-1,4-glucosidase (BG), $\beta-1,4-\mathrm{N}$ acetylglucosaminidase (NAG), leucine aminopeptidase (LAP), and acid (alkaline) phosphatase (AP), Sinsabaugh et al. (2009) observed a mean global ratio of $\mathrm{C}: \mathrm{N}: \mathrm{P}$ acquisition, $\ln (\mathrm{BG}): \ln (\mathrm{NAG}+\mathrm{LAP}): \ln (\mathrm{AP})$, of approximately $1: 1: 1$. This consistent, nearly $1: 1: 1$ ratio of enzymatic activities was proposed to represent the equilibrium between the stoichiometry of microbial biomass and organic matter and the microbial element use efficiencies. Based on this, Sinsabaugh and Follstad Shah (2012) developed a biogeochemical equilibrium model that predicts microbial CUE from the stoichiometry of microbial biomass and organic matter, and the ratios of EEAs under conditions of multiple resource limitation by combining kinetics of enzyme activity, MTE, and EST.

Both TER and CNR are a function of microbial element use efficiency (ratio of element invested in growth over total element uptake), such as CUE, nitrogen use efficiency (NUE), and phosphorus use efficiency (PUE; Fig. 6; Sterner and Elser 2002). Microbes can regulate their element use efficiencies according to their nutrient demand, such that they release elements in excess depending on their $\mathrm{C}$ and nutrient demand (e.g., respiration, $\mathrm{N}$ mineralization). Microbial CUE has been the focus of many studies in biogeochemistry, and its stoichiometric and environmental control and importance within the TER concept has been recently reviewed by Manzoni et al. (2012) and Sinsabaugh et al. (2013). By contrast, we have only little knowledge on the regulation of microbial NUE as well as PUE, although they have been taken into account in some theoretical and conceptual models of organic matter decomposition (e.g., Manzoni and Porporato 2009) or stoichiometric models, in which they are often assumed be constant (Sinsabaugh and Follstad Shah 2012). Mooshammer et al. (2014a) have recently demonstrated, however, that microbial NUE increased with increasing resource $\mathrm{C}: \mathrm{N}$ ratio and that the $\mathrm{C}: \mathrm{N}$ imbalance between resource and microbial biomass was also compensated for by adaptations in NUE and not solely by CUE, as usually assumed. In other words, resource C:N imbalance inversely affects CUE and NUE (Fig. 7). In the framework of TER, we expect that microbial CUE reaches a maximum (Sinsabaugh et al. 2013) below the TER $_{\mathrm{C}: \mathrm{N}}$ when microbial communities are $\mathrm{C}$-limited and $\mathrm{N}$ is in excess, accompanied by a concomitant decrease in NUE. In contrast, above the TER $_{\mathrm{C}: \mathrm{N}}$, microbes are expected to be $\mathrm{N}$ limited, while $\mathrm{C}$ is in excess, and NUE should consequently reach a maximum accompanied by down-regulation of CUE. Such integration of variable microbial nutrient use efficiencies has the potential to facilitate further development and application of CNR and TER to advance 


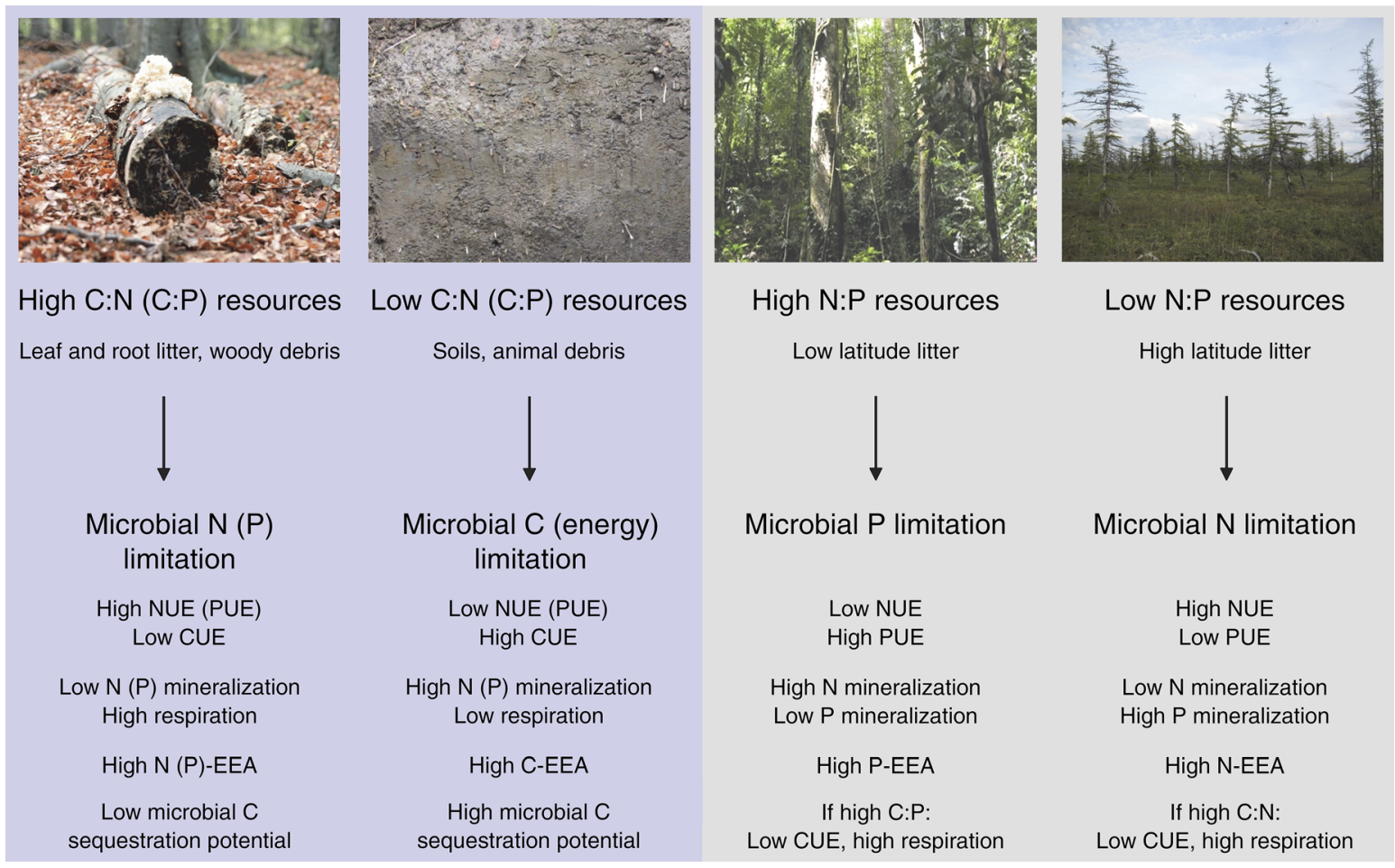

FIG. 7. Hypothetical effects of plant litter and soil C:N:P on microbial processes; CUE, NUE, PUE, C (N, P)-acquiring extracellular enzyme activity [C (N, P)-EEA]. Photo credits (left to right): Alexander Bruckner, Andreas Richter, Wolfgang Wanek, Jörg Schnecker.

our understanding of microbially mediated nutrient fluxes as a response to nutrient limitation.

In addition to adjustments in element use efficiencies, microbial communities can also mobilize resources to meet their elemental demand by producing specific extracellular enzymes in order to alleviate limitations by a particular element. The resource allocation theory proposes that microbial communities maximize their productivity by optimizing their allocation of resources in the production of extracellular $\mathrm{C}-, \mathrm{N}-$, and $\mathrm{P}-$ acquiring enzymes, i.e., increased investment of $\mathrm{C}$ and available nutrients into enzymes mining for limiting nutrients (Sinsabaugh and Moorhead 1994). Phosphatase activity has been shown to be inversely related to inorganic $\mathrm{P}$ availability and to be highly responsive to changes in local nutrient conditions (Olander and Vitousek 2000, Treseder and Vitousek 2001, Allison et al. 2007, Marklein and Houlton 2012). Phosphorus additions thus suppress phosphatase activity, whereas $\mathrm{N}$ additions enhance phosphatase activity, suggesting that microbes may allocate excess $\mathrm{N}$ to phosphatase enzymes (Olander and Vitousek 2000, Marklein and Houlton 2012). Whereas the inverse relationship between phosphatase activity and $\mathrm{P}$ availability is well supported across scales, there is no such simple relationship between $\mathrm{N}$-acquiring EEAs and $\mathrm{N}$ availability at the ecosystem scale (Sinsabaugh and Follstad Shah 2012). This relationship may be masked by the fact that $\mathrm{N}$ acquisition from organic matter (1) is more complex than $\mathrm{P}$ acquisition, and (2) organic $\mathrm{N}$ represents not only an important $\mathrm{N}$ resource but also a $\mathrm{C}$ resource. Organic $\mathrm{P}$ is generally attached by ester bonds, which are easily broken down through hydrolytic phosphatase enzymes (Vitousek and Howarth 1991), allowing microbes to deconstruct organic phosphorus-containing compounds and take up inorganic phosphate without the associated C. By contrast, $\mathrm{N}$-acquisition strategies are linked to the $\mathrm{C}$-substrate preferences of particular taxa, because $\mathrm{N}$ is distributed among several classes of organic polymers as well as humic substances (McGill and Cole 1981). Microbial utilization of organic $\mathrm{N}$ may have different implications for $\mathrm{C}$ and $\mathrm{N}$ mineralization fluxes, as one would predict from simple stoichiometric models, assuming that microorganisms have substrate-specific CUE, which influences their substrate preferences. For example, if $\mathrm{C}$ from $\mathrm{N}$-containing substrates was used with a higher efficiency than $\mathrm{C}$ from $\mathrm{C}$-only substrates, microbes would use $\mathrm{C}$ more efficiently by preferentially utilizing the $\mathrm{N}$-containing substrate, which would increase $\mathrm{N}$ mineralization. In addition, it must be kept in mind that microbes that are $\mathrm{N}$ limited may not be able to allocate resources to extracellular enzymes, as enzymes themselves are N-rich substances that need to be released to the environment and are thus lost for the organism. If microorganisms become severely limited by $\mathrm{N}$, it is likely that they will become dormant until new 
resources become available (Blagodatskaya and Kuzyakov 2013).

Overall, the TER concept is established as a simple but applicable tool for predicting microbial $\mathrm{C}$ and nutrient fluxes. However, even the simple relationship between resource stoichiometry and mineralization fluxes as predicted by CNR theory has not yet been explicitly tested for terrestrial microbial communities. Another important mechanism underlying decomposition and nutrient cycling is the taxonomic composition of the microbial community. Different microorganisms have different enzyme capabilities, and metabolic and stoichiometric characteristics. Certainly, for an accurate representation of stoichiometric relationships in biogeochemical models, we need to account for microbial community dynamics, which have the potential to influence $\mathrm{C}$ and nutrient flow driven by a microbial community response to resource stoichiometry (Kaiser et al. 2014).

\section{Stoichiometric requirements of microbial groups and feedbacks on nutrient availability}

Decomposition rate is not only affected by chemical composition but also by turnover rates, cell size, life history, and shifts in community composition in response to resource stoichiometry. Here we raise the following questions: (1) To what extent are microbial communities related to the nutrient status of the ecosystems? (2) Do global gradients of microbial communities exist? (3) What are the feedbacks of microbial colonization on the substrate stoichiometry?

Resource stoichiometry (C:N:P) affects which microorganisms dominate the decomposition process and the extent to which $\mathrm{N}$ or $\mathrm{P}$ limits growth. Nutrient-poor organic matter is usually dominated by fungi because their nutrient requirements and metabolic activity are lower than in bacteria (Güsewell and Gessner 2009). This explains the lower $\mathrm{P}$ requirements of fungi vs. bacteria (Güsewell and Gessner 2009). Fungal dominance also relates to the higher $\mathrm{N}: \mathrm{P}$ ratios at which fungi become $\mathrm{P}$ limited, whereas bacteria become $\mathrm{P}$ limited at lower N:P ratios (Appendix: Table A1). Besides the ability of fungi to provide enzymes for the degradation of more complex $\mathrm{C}$-rich substrates, which are usually poor in nutrients, their lower $\mathrm{P}$ requirement is probably another explanation for fungal dominance in the decomposition of litter types with higher N:P ratios (Wardle et al. 2004). Within fungi there appear to be differences within phyla, e.g., within the phylum of Ascomycota, Chaetothyriomycetes were related to decomposition in resource-poor environments, while Leotiomycetes and Sordariomycetes were related to decomposition in resource-rich environments (Strickland et al. 2009, Schneider et al. 2012). Within bacteria, Acidobacteria and Actinobacteria were associated with resource environments of lower quality (Strickland et al. 2009). Especially for the Actinobacteria, there is relatively little known about their ecological attributes, but they have a filamentous growth form similar to fungi and therefore are presumed to have the ability to effectively scavenge nutrients. Gram-negative bacteria are favored in soils with high organic matter content (Fierer et al. 2003, Bray et al. 2012) and nitrogen availability (Hossain et al. 2010, Bray et al. 2012). Thus, higher-quality litters tend to be dominated by Gramnegative bacteria while fungi and Gram-positive bacteria are more prevalent on litters of lower quality.

We have summarized recent findings on how resource stoichiometry favors colonization by certain phylogenetic groups, but it also affects life strategies. When organisms have limited access to essential nutrients, natural selection within populations will favor individuals that are most effective at acquiring these nutrients (Strickland and Rousk 2010). Limiting nutrients can be assimilated from the resources through the production of extracellular enzymes. This strategy has costs and benefits that are related to organism life strategies (Allison 2012). With slower growth and turnover rates, $K$-strategists invest more into decomposition of C-rich substrates and have higher cellular $\mathrm{C}: \mathrm{N}$ ratios. With faster growth and turnover rates, $R$-strategists have a larger amount of $\mathrm{N}$ - (and P-) rich ribosomes and also higher mortality rates, resulting in a higher $\mathrm{N}$ demand over time (Kaiser et al. 2014). Thus, $r$-strategists are favored at low substrate C:N ratios, and $K$-strategists are favored at high substrate C:N ratios. Similar to the separation of microbes into $r$ - and $K$-selected organisms (Fierer et al. 2007, Strickland and Rousk 2010) is the differentiation into opportunistic microorganisms, which are characterized to use broadly different pools of organic matter, and show high growth rates as they have a high affinity to soluble substrates (Moorhead and Sinsabaugh 2006), and "miners," which are characterized by the use of lignin as a substrate, and grow rather slowly (Moorhead and Sinsabaugh 2006, Hättenschwiler et al. 2011).

Resource quality and nutrient availability promote the establishment of certain phylogenetic as well as physiological groups; in addition, the type of microbial interactions with each other and with plants can be affected. Thrall et al. (2007) hypothesized that mutualistic associations most likely arise in nutrient-limited environments and parasitic associations are most likely in high-fertility environments, i.e., under nutrient surplus. At high enzyme-production rates, the community changes toward cheaters (organisms who do not synthesize enzymes but take up product; Allison 2005), and the community that produces a broad spectrum of enzymes declines. Taxa that produce few or no enzymes (cheaters) can survive or even accumulate to high abundances when enzyme production by miners is high. When total enzyme production is low, it seems to be advantageous for microbes to produce a broad range of enzymes, and remains still favorable as cheater populations increase (Allison 2012). Positive associations tend to reduce the selection for a distinct suite of enzymes, by 
taking up monomers provided by other microbes. These community dynamics were related to rates of litter decomposition. Low rates of enzyme production resulted in linear increases in litter decomposition rates, while high rates of enzyme production led to a saturation of decomposition rates (Allison 2012). While cheating is an antagonistic relationship between microbes, different trends of interactions with plants can also be observed.

Mycorrhizal fungi have developed especially efficient P-uptake strategies. This promotes the proportion of mycorrhizal fungal hyphae, increasing the N:P ratio of the microbial biomass in P-deficient systems. Mycorrhizal fungi deliver $P$ to their host plants, even though they have higher tissue $\mathrm{P}$ concentrations and lower N:P ratios (ectomycorrhizae biomass N:P ratio 11.3; Appendix: Table A1; Wallander et al. 2002, 2003) than plants. This is probably because their superior $\mathrm{P}$ acquisition allows them to readily satisfy their own needs, creating a surplus that can be used in C-for-P trade (Johnson 2010). These examples illustrate how fungi can deal with higher resource stoichiometries and feedback on the nutrient status of the ecosystem by lowering N:P ratios for plants.

In boreal forests, which are typically $\mathrm{N}$ limited, ericoid mycorrhizal fungi can also deliver simple organic $\mathrm{N}$ compounds to their host plants (Näsholm et al. 1998). In contrast, arbuscular mycorrhizae (AM) in the tropics are highly efficient $\mathrm{P}$ mobilizers. Ericoid mycorrhizae dominate cold and wet environments that contain high $\mathrm{C}: \mathrm{N}$ litter, and ectomycorrhizae dominate ecosystems containing litter with intermediate $\mathrm{C}: \mathrm{N}$ ratios. AM occur in warmer ecosystems containing lower C:N litter, which is more easily mineralized but tends to be $\mathrm{P}$ limited (Johnson 2010). Generally, across large latitudinal gradients, there appears to be a strong relationship between litter quality, the humus that arises from it, and the predominant form of microbes (saprotrophs or mycorrhizae) that exploit soil resources (Read 1991). These global patterns of different types of mycorrhizae illustrate how fungi can reduce $\mathrm{N}$ limitation in boreal areas and $\mathrm{P}$ limitation in the tropics.

We conclude that (1) microbial communities respond to the nutrient status of the ecosystem on a phylogenetic level as well as by life strategy. Some saprotrophic fungi and bacteria with hyphal growth use their advantage of easier access to external $\mathrm{N}$ and $\mathrm{P}$ and thrive under nutrient-poor conditions as miners. (2) Global gradients from $\mathrm{N}$ limitation in boreal forests to $\mathrm{P}$ limitation in the tropics are reflected by different forms of mycorrhizae. (3) In the examples mentioned, microbial groups help alleviate $\mathrm{N}$ and $\mathrm{P}$ limitations.

How Does Global Change Affect the Mechanisms of Plant and Microbial Nutrient Cycling?

\section{Enhanced $\mathrm{CO}_{2}$}

Under rising atmospheric $\mathrm{CO}_{2}$, plant $\mathrm{C}: \mathrm{N}$ and $\mathrm{C}: \mathrm{P}$ ratios generally increase in $\mathrm{C}_{3}$ plants, but not in $\mathrm{C}_{4}$ plants (Sardans et al. 2012a). A recent meta-analysis of
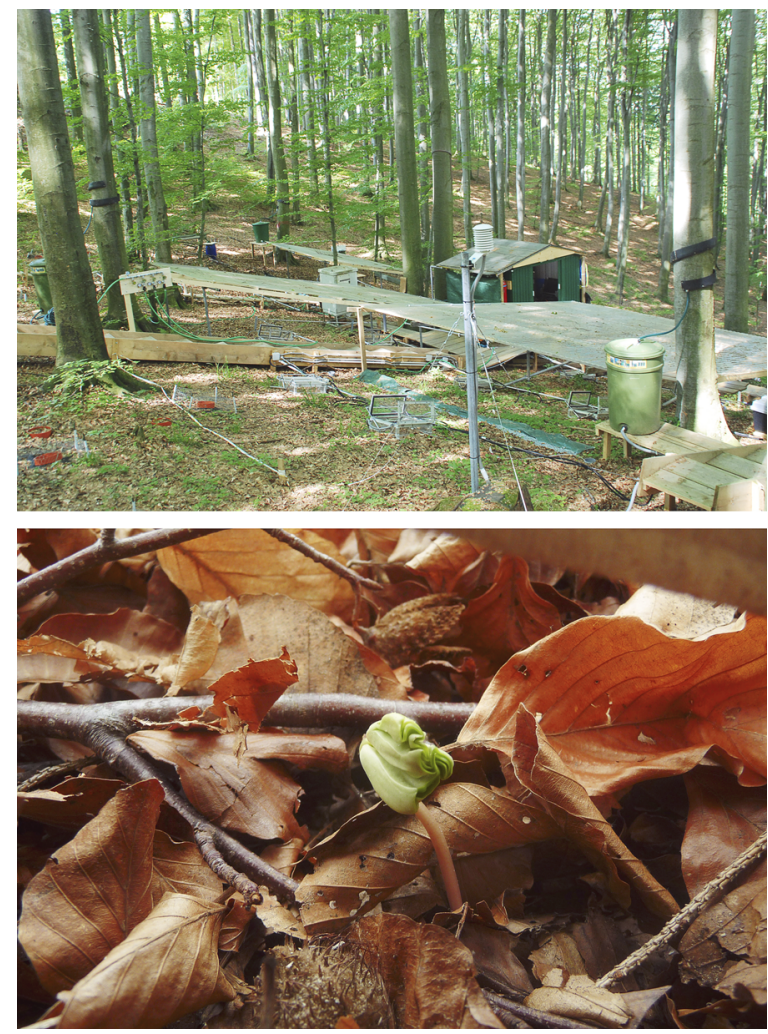

Plate 1. The stoichiometry of litter decomposition is affected by climate change as investigated at the experimental site Lehrforst Rosalia, Lower Austria. Photo credits: Sonja Leitner.

atmospheric $\mathrm{CO}_{2}$ enrichment experiments at concentrations projected for the coming decades revealed overall increases in leaf C:N and C:P ratios (22\% and 38\%, respectively) in $\mathrm{C}_{3}$ plants (Sardans et al. 2012a). These increases in plant $\mathrm{C}$ : nutrient ratios translate to higher soil $\mathrm{C}$ : nutrient ratios, despite the usual absence of observed effects on soil fertility (Sardans and Peñuelas 2012). Moreover, recent studies give strong evidence that increasing atmospheric $\mathrm{CO}_{2}$ induces higher foliar $\mathrm{N}: \mathrm{P}$ ratios (AbdElgawad et al. 2014, Yang et al. 2014).

By affecting plant stoichiometry, enhanced $\mathrm{CO}_{2}$ affects microbial turnover rates in the soil, theoretically resulting in slower decomposition and reduced $\mathrm{N}$ availability. However, the water status of an ecosystem largely determines the $\mathrm{CO}_{2}$ impact on mineralization (Garten et al. 2009). To be specific, the effects of enhanced $\mathrm{CO}_{2}$ on soil $\mathrm{N}$ availability depend on the balance between enhanced microbial $\mathrm{N}$ mineralization and increased $\mathrm{N}$ demands by plants (Reich et al. 2006). This, in turn, is affected by water availability. For instance, $\mathrm{N}_{2} \mathrm{O}$ emission (indicating $\mathrm{N}$ overflow metabolism) was enhanced in $\mathrm{CO}_{2}$ enrichment experiments in humid grasslands (e.g., Regan et al. 2011), but reduced or unchanged in similar experiments in semiarid shortgrass steppe (Mosier et al. 2002) and desert (Billings et al. 2002). Likewise, enhanced $\mathrm{N}$ mineralization was 
observed under enhanced $\mathrm{CO}_{2}$ and warming in northern, moist ecosystems (Bengtson et al. 2012). The authors explain these results as increased belowground $\mathrm{C}$ allocation by root exudates. This stimulated the growth of microbial biomass with a $\mathrm{C}: \mathrm{N}$ ratio of 7.8, triggering a priming effect leading to SOM decomposition (Bengtson et al. 2012). We therefore assume that $\mathrm{N}$ availability can even be stimulated by enhanced $\mathrm{CO}_{2}$ under the condition that soil moisture and temperature are not limiting microbial activity. This is in line with global model predictions claiming that on the decadal time scale, $\mathrm{CO}_{2}$-stimulated plant growth will attenuate, and the effect of increased inorganic $\mathrm{N}$ mineralization due to climate change will tend to overwhelm the plant $\mathrm{N}$ uptake rate (Xu et al. 2012). If this holds true, then the combination of increased $\mathrm{CO}_{2}$ and warming would even increase $\mathrm{N}$ availability, provided that there is sufficient soil moisture.

\section{$N$ eutrophication}

Anthropogenic $\mathrm{N}$ eutrophication is a current driver of global change that is severely affecting the $\mathrm{C}: \mathrm{N}$ and $\mathrm{N}: \mathrm{P}$ ratios of soils and terrestrial plants (Sardans et al. 2012a, Peñuelas et al. 2013a). Two contrasting situations exist. In areas with intense pastoral activity and use of animal slurry as fertilizer, the N:P ratios of soils have decreased (Arbuckle and Downing 2001, Peñuelas et al. 2009). Cropland is heavily and continuously fertilized with livestock wastes that have $\mathrm{N}: \mathrm{P}$ ratios of $\sim 3: 1$, when crop requirements are generally 10:1 or more (Gilliam 1995, McFarland and Hauck 2004). The P-fixing capacity of the soil is thus exceeded (Gilliam 1995), producing even lower N:P ratios over time. This is because $\mathrm{P}$ is less soluble than $\mathrm{N}$ and therefore tends to accumulate in soil more than N does (Gilliam 1995, McFarland and Hauck 2004).

On a global scale, the continuous increase of $\mathrm{N}: \mathrm{P}$ ratios of all types of inputs resulting from human activities leads to a progressive global increase in plantavailable N:P ratios (Peñuelas et al. 2012, 2013a). Anthropogenic applications of $\mathrm{P}$ from mineral fertilizers, livestock slurry, and manure reach $22-26 \mathrm{Tg} \mathrm{P} / \mathrm{yr}$ and have been nearly constant since 1989 (see detailed information in Peñuelas et al. [2012, 2013a]). In contrast, global anthropogenic inputs of $\mathrm{N}$, including reactive $\mathrm{N}$ from fossil fuel combustion, industrial $\mathrm{N}$ fertilizers, and biological fixation of atmospheric $\mathrm{N}_{2}$ by cultivated leguminous crops and rice, are 208-216 Tg N/yr and continue to increase (Peñuelas et al. 2012). Unlike N, P is not volatile, so very little $\mathrm{P}$ is redistributed from cropland to nearby natural terrestrial ecosystems. For example, the atmospheric molar N:P deposition ratio is currently 44-47 over land, approximately twice the molar ratio in terrestrial plants (22-30). Over the oceans it is $114-370$, which considerably exceeds the Redfield ratio (Peñuelas et al. 2013a). Projections of future N emissions suggest an expansion of the area with high anthropogenic $\mathrm{N}$ deposition and high deposited $\mathrm{N}: \mathrm{P}$ ratios from the populated temperate regions of the Northern Hemisphere into tropical regions (Lamarque et al. 2010, Hietz et al. 2011, Peñuelas et al. 2013a). Available studies show a $25 \%$ average decrease in foliar $\mathrm{C}: \mathrm{N}$ ratios in response to simulated experimental $\mathrm{N}$ deposition (Sardans et al. 2012a). Even though N inputs accelerate P cycles (Marklein and Houlton 2012) and reduce the abundance of $\mathrm{N}_{2}$ fixers, these inputs are frequently insufficient to equilibrate plant $\mathrm{N}: \mathrm{P}$ stoichiometry and to prevent an increase in the N:P ratios of organisms and ecosystems. $\mathrm{N}$ deposition therefore increases the $\mathrm{N}: \mathrm{P}$ ratios of terrestrial plants. This potentially alters the species composition of communities, reduces the community of $\mathrm{N}_{2}$ fixers in the soil, and reduces species diversity (Sardans et al. 2012a, Peñuelas et al. 2013a). We can expect that plant and litter N:P ratios will increase in the short term in areas with continuous loadings of high N:P ratios. Moreover, species with high leaf and litter $\mathrm{N}: \mathrm{P}$ ratios will be favored in the medium to long term, with further consequences on soil trophic webs (Peñuelas et al. 2012, 2013a, Sardans et al. 2012a). We can also expect that N saturation will decrease $\mathrm{N}$ resorption and increase the litter $\mathrm{N}: \mathrm{P}$ ratio, thus altering the role of $\mathrm{P}$ limitation in soil trophic webs (Kozovits et al. 2007, Jacobson et al. 2011).

Because of stoichiometrically coupled $\mathrm{C}$ and $\mathrm{N}$ cycles, $\mathrm{N}$ eutrophication affects $\mathrm{C}$ sequestration in soils, which constitute the largest terrestrial $\mathrm{C}$ pool. Increasing $\mathrm{N}$ inputs to natural ecosystems promote plant growth and hence also increase $\mathrm{C}$ inputs to the soil litter layer. At the same time, trees invest a smaller fraction of $\mathrm{C}$ into root growth and exudates, the latter potentially inhibiting mycorrhizal fungi and rhizosphere-inhabiting bacteria (Högberg 2010, Högberg et al. 2010, Luo and Zhou 2010). This leads to uncertain consequences for longterm $\mathrm{C}$ sequestration.

\section{Warming and drought}

Elevated concentrations of atmospheric greenhouse gases have changed the global climate, raising Earth's surface temperature by $0.74^{\circ} \mathrm{C}$ in the past century and changing the intensity of precipitation in several areas of the world (IPCC 2007). Most studies suggest that warming and drought increase plant $\mathrm{C}: \mathrm{N}$ and $\mathrm{C}: \mathrm{P}$ ratios in currently warm-dry and temperate-dry ecosystems by mechanisms associated with water conservation and increased nutrient use efficiencies (Sardans et al. 2012a). These effects can be even higher if warming and drought coincide and if the atmospheric concentration of $\mathrm{CO}_{2}$ continues to rise (Sardans et al. 2012a). Such changes in C:N:P stoichiometry are accompanied by other changes in leaf chemistry. These include increases in the concentrations of $\mathrm{K}$, cellular osmolytes (including sugars and amino acids), and secondary metabolites that are normally C-rich antistress compounds such as phenolics (Rivas-Ubach et al. 2012). These effects are also frequently associated with 
reduced water uptake by plants (Peñuelas et al. 2013b), with decreased activity of soil enzymes, and with reduced availability of $\mathrm{N}$ and $\mathrm{P}$ (Sardans and Peñuelas 2012). Under more arid conditions, increases in litter C:N and C:P ratios (Sardans et al. 2012b) and slow returns of nutrients from leaf litter to soil are expected and have already been observed (Saura-Mas et al. 2012).

The effects of warming on C:N and C:P ratios at high latitudes, however, are less clear. This suggests a strong dependence on the richness of soil nutrients and on interactions with other drivers of global change, such as $\mathrm{N}$ deposition (Aerts et al. 2012). Some studies report lower plant $\mathrm{C}: \mathrm{N}$ ratios after increases in nutrient uptake associated with higher soil biological activity and nutrient availability (Welker et al. 2005, Aerts et al. 2009). In a recent meta-analysis, Aerts et al. (2012) calculated an increase in $\mathrm{C}: \mathrm{N}$ ratios in the litter of subarctic flora in response to warming. Recent studies are providing continuous evidence that increasing drought and warming raise plant N:P ratios (Dijkstra et al. 2012, Yang et al. 2013). The several potential implications, including changes in soil processes, warrant future research.

Soil C mineralization shows higher temperature sensitivity than $\mathrm{N}$ mineralization, and the latter is more dependent on soil moisture (Beier et al. 2008). The results suggest that $\mathrm{C}$ and $\mathrm{N}$ cycles respond asymmetrically to warming, which may lead to progressive $\mathrm{N}$ limitation and thereby acclimation in plant production. The microbial $\mathrm{C}$ and $\mathrm{N}$ cycles are also coupled via oxygen consumption. This means that temperature can indirectly affect microbial $\mathrm{N}$ turnover by stimulating soil respiration: this will promote anaerobic conditions in moist soils, thereby accelerating $\mathrm{N}$ losses via denitrification (Veraart et al. 2011, Butterbach-Bahl et al. 2013). Soil warming by $4^{\circ} \mathrm{C}$ in a mountain forest did not significantly affect microbial biomass or community composition, but it did increase soil respiration by $40 \%$ and significantly reduce CUE of microbes (Schindlbacher et al. 2011). Nonetheless, the stimulating soil warming effect on decomposition was offset by prolonged summer droughts (Schindlbacher et al. 2012). This supports our expectation that warming in combination with arid conditions will slow down nutrient cycling between plants, litter, and soil.

From this, we deduce that global change effects on the stoichiometry of nutrient recycling largely depend on the soil water status (see Plate 1). This holds true for enhanced $\mathrm{CO}_{2}$ as well as for nitrogen inputs to ecosystems; likewise the impacts of global warming on plant $\mathrm{C}: \mathrm{N}$ and $\mathrm{C}: \mathrm{P}$ ratios, and soil $\mathrm{C}$ sequestration may be obscured by moisture conditions.

\section{Conclusions}

This review demonstrates that a stoichiometric perspective facilitates interpretation of the linkage between above- and belowground systems, the socalled green and brown worlds. In answer to our question (1), we found evidence that latitudinal gradients of stoichiometry do exist, but with different trends for plant tissue and litter and soil organic matter and microbial biomass. This apparent paradox can be solved by looking into plant and microbial physiology in the light of stoichiometric concepts, which allow for positive and negative feedback effects on substrate $\mathrm{N}$ and $\mathrm{P}$ availability. Foliar $\mathrm{N}$ and $\mathrm{P}$ are resorbed less at $\mathrm{N}$ - and P-rich sites and under optimal climatic conditions than at $\mathrm{N}$ - and P-poor sites. Thus, lower litter nutritional quality coincides with nutrient-poor sites and nonoptimal climatic conditions, constituting a positive feedback with negative consequences for the soil trophic web. Plant nutrient resorption efficiency is higher on nutrient-poor soils. The lower nutrient concentration in litter results in reduced decomposition rates, nutrient release, and energy and matter transfer to the other trophic levels. Moreover, compared to N, $P$ shows higher variability in resorption efficiency and higher resorption sensitivity to nutrient availability, features that are very important for $\mathrm{P}$ conservation in plants and for final litter N:P stoichiometry. Sites exhibiting litter low in $\mathrm{N}$ and $\mathrm{P}$ tend to show microbial nutrient immobilization during decay (question 2). This leads to a forest floor depleted of available nutrients and perpetuates nutrient deficiency for plant growth. However, standing crops of undecomposed litter progressively slow down mineral leaching and soil erosion and hence help conserve nutrients in ecosystems, i.e., a negative feedback on $\mathrm{N}$ and $\mathrm{P}$ depletion. In addition, the microbial decomposition process triggers a convergence of $\mathrm{C}: \mathrm{N}: \mathrm{P}$ ratios due to the largely homeostatic nature of microbes. On a microbialcommunity level, microbial groups such as bacterial and fungal miners with hyphal growth and specific types of mycorrhizae alleviate $\mathrm{N}$ - and P- limitations, respectively, and thereby help lower stoichiometric constraints for plants. Besides these explanations, other underlying mechanisms of latitudinal trends in stoichiometry are complex, involving chemical and physical stabilization processes of organic debris, and strong impacts of climate, which opens up a vast field of future research. In particular, the interactive effects of different global change drivers demand a better understanding, as well as microbial element use efficiencies and their temperature and moisture sensitivities.

We report that many studies on aspects of global change suggest that warming, drought, and $\mathrm{CO}_{2}$ enrichment increase plant $\mathrm{C}: \mathrm{N}$ and $\mathrm{C}: \mathrm{P}$ ratios by mechanisms associated with water conservation and increased nutrient and water use efficiency (question 3). These increases in plant $C$ : nutrient ratios translate to higher topsoil $\mathrm{C}$ : nutrient ratios, slowing down nutrient recycling and microbial SOM decomposition. Under moist conditions, opposite effects can be expected to be 
triggered by priming and enhanced mineralization processes under high $\mathrm{CO}_{2}$ and warming. We therefore suggest introducing stoichiometric regulation of the growth and activity of plants as well as soil microorganisms into process-based models and linking these with regionalized climate scenarios which include future rainfall patterns (Sistla et al. 2014). Better knowledge of stoichiometric regulation of $\mathrm{N}$ and $\mathrm{P}$ availability under predicted temperature/moisture regimes will help better understanding future nutrient cycling in a changing world.

\section{ACKNOWLEDGMENTS}

Special thanks to Bruce R. James for comments on earlier drafts on the manuscript and to Michael Stachowitsch for linguistic refinement. This manuscript is an outcome of the MICDIF integrated project (linking microbial diversity and function across scales and ecosystems), funded by the Austrian Science Fund FWF (S 10006-B01, S 10006-B06, S 10006B07). J. Peñuelas' and J. Sardans' research was supported by Spanish government grants CGL2013-48074-P and ConsoliderIngenio Montes CSD2008-00040, and Catalan government grant SGR 2014-274. Thanks to Håkan Wallander and Markus Gorfer for information on mycorrhizal and fungal biomass stoichiometry and to the reviewers for their time and effort and inspiring comments.

\section{Literature Cited}

AbdElgawad, H., D. Peshev, G. Zinta, W. Van den Ende, I. A. Janssens, and H. Asard. 2014. Climate extreme effects on the chemical composition of temperate grassland species under ambient and elevated $\mathrm{CO}_{2}$ : a comparison of fructan and nonfructan accumulators. PLoS ONE 9(3):e92044.

Aber, J. D., and J. M. Melillo. 1980. Litter decomposition: measuring relative contributions of organic-matter and nitrogen to forest soils. Canadian Journal of Botany 58:416-421.

Aerts, R. 1996. Nutrient resorption from senescing leaves of perennials: are there general patterns? Journal of Ecology 84:597-608.

Aerts, R. 1997a. Climate, leaf litter chemistry and leaf litter decomposition in terrestrial ecosystems: a triangular relationship. Oikos 79:439-449.

Aerts, R. 1997b. Nitrogen partitioning between resorption and decomposition pathways: a trade-off between nitrogen use efficiency and litter decomposibility? Oikos 80:603-606.

Aerts, R., T. V. Callaghan, E. Dorrepaal, R. S. P. van Logtestijn, and J. H. C. Cornelissen. 2009. Seasonal climate manipulations result in species-specific changes in leaf nutrient levels and isotopic composition in a sub-arctic bog. Functional Ecology 23:680-688.

Aerts, R., and F. S. Chapin, III. 2000. The mineral nutrition of wild plants revisited: a re-evaluation of processes and patterns. Pages 1-67 in A. H. Fitter and D. G. Raffaelli, editors. Advances in ecological research. Volume 30. Academic Press, London, UK.

Aerts, R., P. M. van Bodegom, and J. H. C. Cornelissen. 2012. Litter stoichiometric traits of plant species of high-latitude ecosystems show high responsiveness to global change without causing strong variation in litter decomposition. New Phytologist 196:181-188.

Ågren, G. I., E. Bosatta, and A. H. Magill. 2001. Combining theory and experiment to understand effects of inorganic nitrogen on litter decomposition. Oecologia 128:94-98.
Allen, A. P., and J. F. Gillooly. 2009. Towards an integration of ecological stoichiometry and the metabolic theory of ecology to better understand nutrient cycling. Ecology Letters 12:369-384.

Allison, S. D., 2005. Cheaters, diffusion and nutrients constrain decomposition by microbial enzymes in spatially structured environments. Ecology Letters 8:626-635.

Allison, S. D. 2012. A trait-based approach for modelling microbial litter decomposition. Ecology Letters 15:10581070.

Allison, V. J., L. M. Condron, D. A. Peltzer, S. J. Richardson, and B. L. Turner. 2007. Changes in enzyme activities and soil microbial community composition along carbon and nutrient gradients at the Franz Josef chronosequence, New Zealand. Soil Biology \& Biochemistry 39:1770-1781.

Anderson, T. R., and D. O. Hessen. 1995. Carbon or nitrogen limitation in marine copepods? Journal of Plankton Research 17:317-331.

Aneja, M. K., S. Sharma, F. Fleischmann, S. Stich, W. Heller, G. Bahnweg, J. C. Munch, and M. Schloter. 2006. Microbial colonization of beech and spruce litter: influence of decomposition site and plant litter species on the diversity of microbial community. Microbial Ecology 52:127-135.

Arbuckle, K. E., and J. A. Downing. 2001. The influence of watershed land use on lake N:P in a predominantly agricultural landscape. Limnology and Oceanography 46:970-975.

Austin, A. T., and P. M. Vitousek. 2012. Introduction to a Virtual Special Issue on ecological stoichiometry and global change. New Phytologist 196:649-651.

Averill, C. 2014. Divergence in plant and microbial allocation strategies explains continental patterns in microbial allocation and biogeochemical fluxes. Ecology Letters 17(10):12021210.

Beier, C., et al. 2008. Carbon and nitrogen cycles in European ecosystems respond differently to global warming. Science of the Total Environment 407:692-697.

Bengtson, P., J. Barker, and S. J. Grayston. 2012. Evidence of a strong coupling between root exudation, $\mathrm{C}$ and $\mathrm{N}$ availability, and stimulated SOM decomposition caused by rhizosphere priming effects. Ecology and Evolution 2:18431852.

Berg, B., and C. McClaugherty. 2003. Plant litter: decomposition, humus formation, carbon sequestration. SpringerVerlag, Berlin, Germany.

Billings, S. A., S. M. Schaeffer, and R. D. Evans. 2002. Trace N gas losses and $\mathrm{N}$ mineralization in Mojave Desert soils exposed to elevated $\mathrm{CO}_{2}$. Soil Biology \& Biochemistry 34:1777-1784.

Blagodatskaya, E., and Y. Kuzyakov. 2013. Active microorganisms in soil: critical review of estimation criteria and approaches. Soil Biology \& Biochemistry 67:192-211.

Borer, E. T., et al. 2013. Global biogeography of autotroph chemistry: is insolation a driving force? Oikos 122:1121-1130.

Bray, S. R., K. Kitajima, and M. C. Mack. 2012. Temporal dynamics of microbial communities on decomposing leaf litter of 10 plant species in relation to decomposition rate. Soil Biology \& Biochemistry 49:30-37.

Bridgham, S. D., and C. J. Richardson. 2003. Endogenous vs. exogenous nutrient control over decomposition and mineralization in North Carolina peatlands. Biogeochemistry 65:151-178.

Brovkin, V., P. M. van Bodegom, T. Kleinen, C. Wirth, W. K. Cornwell, J. H. C. Cornelissen, and J. Kattge. 2012. Plant- 
driven variation in decomposition rates improves projections of global litter stock distribution. Biogeosciences 9:565-576.

Brown, J. H., J. F. Gillooly, A. P. Allen, V. M. Savage, and G. B. West. 2004. Toward a metabolic theory of ecology. Ecology 85:1771-1789.

Butterbach-Bahl, K., E. M. Baggs, M. Dannenmann, R. Kiese, and S. Zechmeister-Boltenstern. 2013. Nitrous oxide emissions from soils: how well do we understand the processes and their controls? Philosophical Transactions of the Royal Society B 368:2013012.

Campioli, M., A. Michelsen, A. Demey, A. Vermeulen, R. Samson, and R. Lemeur. 2009. Net primary production and carbon stocks for subarctic mesic-dry tundras with contrasting microtopography, altitude, and dominant species. Ecosystems 12:760-776.

Cardenas, I., and J. Campo. 2007. Foliar nitrogen and phosphorus resorption and decomposition in the nitrogenfixing tree Lysiloma microphyllum in primary and secondary seasonally tropical dry forests in Mexico. Journal of Tropical Ecology 23:107-113.

Chapin, F. S., III, N. Fetcher, K. Kielland, K. R. Everett, and A. E. Linkins. 1988. Productivity and nutrient cycling in Alaskan tundra: enhancement by flowing soil water. Ecology 69:693-702.

Chuyong, C. B., D. M. Newbery, and N. C. Songwe. 2000. Litter nutrients and retranslocation in a central African rain forest dominated by ectomycorrhizal trees. New Phytologist 148:493-510.

Cleveland, C. C., and D. Liptzin. 2007. C:N:P stoichiometry in soil: is there a "Redfield ratio" for the microbial biomass? Biogeochemistry 85:235-252.

Cornwell, W. K., et al. 2008. Plant species traits are the predominant control on litter decomposition rates within biomes worldwide. Ecology Letters 11:1065-1071.

Côté, B., J. W. Fyles, and H. Djalilvand. 2002. Increasing N and $\mathrm{P}$ resorption efficiency and proficiency in northern deciduous hardwoods with decreasing foliar $\mathrm{N}$ and $\mathrm{P}$ concentrations. Annals of Forest Science 59:275-281.

Dijkstra, F. A., E. Pendall, J. A. Morgan, D. M. Blumenthal, Y. Carrillo, D. R. LeCain, R. F. Follett, and D. G. Williams. 2012. Climate change alters stoichiometry of phosphorus and nitrogen in a semiarid grassland. New Phytologist 196:807815.

Doi, H., M. Cherif, T. Iwabuchi, I. Katano, J. C. Stegen, and M. Striebel. 2010. Integrating elements and energy through the metabolic dependencies of gross growth efficiency and the threshold elemental ratio. Oikos 119:752-765.

Elser, J. J., M. E. S. Bracken, E. E. Cleland, D. S. Gruner, W. S. Harpole, H. Hillebrand, J. T. Ngai, E. W. Seabloom, J. B. Shurin, and J. E. Smith. 2007. Global analysis of nitrogen and phosphorus limitation of primary producers in freshwater, marine and terrestrial ecosystems. Ecology Letters 10:1135-1142.

Elser, J. J., D. R. Dobberfuhl, N. A. MacKay, and J. H. Schampel. 1996. Organism size, life history, and N:P stoichiometry. Bioscience 46:674-684.

Elser, J. J., R. W. Sterner, E. Gorokhova, W. F. Fagan, T. A. Markow, J. B. Cotner, J. F. Harrison, S. E. Hobbie, G. M. Odell, and L. J. Weider. 2000. Biological stoichiometry from genes to ecosystems. Ecology Letters 3:540-550.

Elser, J. J., and J. Urabe. 1999. The stoichiometry of consumerdriven nutrient recycling: theory, observations, and consequences. Ecology 80:735-751.

Enríquez, S., C. M. Duarte, and K. Sandjensen. 1993. Patterns in decomposition rates among photosynthetic organisms: the importance of detritus $\mathrm{C}: \mathrm{N}: \mathrm{P}$ content. Oecologia 94:457-471.

Fierer, N., M. A. Bradford, and R. B. Jackson. 2007. Toward an ecological classification of soil bacteria. Ecology 88:13541364.

Fierer, N., J. P. Schimel, and P. A. Holden. 2003. Variations in microbial community composition through two soil depth profiles. Soil Biology \& Biochemistry 35:167-176.

Finer, L., M. Ohashi, K. Noguchi, and Y. Hirano. 2011 a. Factors causing variation in fine root biomass in forest ecosystems. Forest Ecology and Management 261:265-277.

Finer, L., M. Ohashi, K. Noguchi, and Y. Hirano. 2011b. Fine root production and turnover in forest ecosystems in relation to stand and environmental characteristics. Forest Ecology and Management 262:2008-2023.

Freschet, G. T., R. Aerts, and J. H. C. Cornelissen. 2012. A plant economics spectrum of litter decomposability. Functional Ecology 26:56-65.

Freschet, G. T., J. H. C. Cornelissen, R. S. P. van Logtestijn, and R. Aerts. 2010. Substantial nutrient resorption from leaves, stems and roots in a subarctic flora: what is the link with other resource economics traits? New Phytologist 186:879-889.

Freschet, G. T., W. K. Cornwell, D. A. Wardle, T. G. Elumeeva, W. D. Liu, B. G. Jackson, V. G. Onipchenko, N. A. Soudzilovskaia, J. P. Tao, and J. H. C. Cornelissen. 2013. Linking litter decomposition of above- and belowground organs to plant-soil feedbacks worldwide. Journal of Ecology 101:943-952.

Frost, P. C., J. P. Benstead, W. F. Cross, H. Hillebrand, J. H. Larson, M. A. Xenopoulos, and T. Yoshida. 2006. Threshold elemental ratios of carbon and phosphorus in aquatic consumers. Ecology Letters 9:774-779.

Garten, C. T., Jr., A. T. Classen, and R. J. Norby. 2009. Soil moisture surpasses elevated $\mathrm{CO}_{2}$ and temperature as a control on soil carbon dynamics in a multi-factor climate change experiment. Plant and Soil 319:85-94.

Gilliam, J. W. 1995. Phosphorus control strategies. Ecological Engineering 5:405-414.

Gordon, W. S., and R. B. Jackson. 2000. Nutrient concentrations in fine roots. Ecology 81:275-280.

Güsewell, S., and C. Freeman. 2005. Nutrient limitation and enzyme activities during litter decomposition of nine wetland species in relation to litter N:P ratios. Functional Ecology 19:582-593.

Güsewell, S., and M. O. Gessner. 2009. N:P ratios influence litter decomposition and colonization by fungi and bacteria in microcosms. Functional Ecology 23:211-219.

Han, W. X., L. Y. Tang, Y. H. Chen, and J. Y. Fang. 2013. Relationship between the relative limitation and resorption efficiency of nitrogen vs. phosphorus in woody plants. PLoS ONE 8(12):e83366.

Harmon, M. E., et al. 1986. Ecology of coarse woody debris in temperate ecosystems. Advances in Ecological Research 15:133-302.

Hartman, W. H., and C. J. Richardson. 2013. Differential nutrient limitation of soil microbial biomass and metabolic quotients $\left(q \mathrm{CO}_{2}\right)$ : is there a biological stoichiometry of soil microbes? PLoS ONE 8(3):e57127.

Hättenschwiler, S., B. Aeschlimann, M. M. Couteaux, J. Roy, and D. Bonal. 2008. High variation in foliage and leaf litter chemistry among 45 tree species of a neotropical rainforest community. New Phytologist 179:165-175.

Hättenschwiler, S., N. Fromin, and S. Barantal. 2011. Functional diversity of terrestrial microbial decomposers 
and their substrates. Comptes Rendus Biologies 334:393402.

Hättenschwiler, S., and H. B. Jorgensen. 2010. Carbon quality rather than stoichiometry controls litter decomposition in a tropical rain forest. Journal of Ecology 98:754-763.

Hedin, L. O., P. M. Vitousek, and P. A. Matson. 2003. Nutrient losses over four million years of tropical forest development. Ecology 84:2231-2255.

Hietz, P., B. L. Turner, W. Wanek, A. Richter, C. A. Nock, and S. J. Wright. 2011. Long-term change in the nitrogen cycle of tropical forests. Science 334:664-666.

Högberg, M. N., et al. 2010. Quantification of effects of season and nitrogen supply on tree below-ground carbon transfer to ectomycorrhizal fungi and other soil organisms in a boreal pine forest. New Phytologist 187:485-493.

Högberg, P. 2010. Is tree root respiration more sensitive than heterotrophic respiration to changes in soil temperature? New Phytologist 188:9-10.

Holloway, J. M., and R. A. Dahlgren. 2002. Nitrogen in rock: occurrences and biogeochemical implications. Global Biogeochemical Cycles 16(4):65-1-65-17.

Hossain, M. Z., A. Okubo, and S. Sugiyama. 2010. Effects of grassland species on decomposition of litter and soil microbial communities. Ecological Research 25:255-261.

Hui, D. F., and R. B. Jackson. 2006. Geographical and interannual variability in biomass partitioning in grassland ecosystems: a synthesis of field data. New Phytologist 169:85-93.

IPCC. 2007. Contribution of Working Group I to the fourth Assessment Report of the Intergovernmental Panel on Climate Change. Cambridge University Press, Cambridge, UK.

Jacobson, T. K., M. M. Bustamante, and A. R. Kozovits. 2011. Diversity of shrub tree layer, leaf litter decomposition and $\mathrm{N}$ release in a Brazilian Cerrado under $\mathrm{N}, \mathrm{P}$ and $\mathrm{N}$ plus $\mathrm{P}$ additions. Environmental Pollution 159:2236-2242.

Johnson, N. C. 2010. Resource stoichiometry elucidates the structure and function of arbuscular mycorrhizas across scales. New Phytologist 185:631-647.

Kaiser, C., O. Franklin, U. Dieckmann, and A. Richter. 2014. Microbial community dynamics alleviate stoichiometric constraints during litter decay. Ecology Letters 17:680-690.

Kang, H., Z. Xin, B. Berg, P. J. Burgess, Q. Liu, Z. Liu, Z. Li, and C. Liu. 2010. Global pattern of leaf litter nitrogen and phosphorus in woody plants. Annals of Forest Science 67:811.

Karpinets, T. V., D. J. Greenwood, C. E. Sams, and J. T. Ammons. 2006. RNA: protein ratio of the unicellular organism as a characteristic of phosphorous and nitrogen stoichiometry and of the cellular requirement of ribosomes for protein synthesis. BMC Biology 4:30.

Kattge, J., et al. 2011. TRY: a global database of plant traits. Global Change Biology 17:2905-2935.

Keiblinger, K. M., et al. 2012. Effects of stoichiometry and temperature perturbations on beech leaf litter decomposition, enzyme activities and protein expression. Biogeosciences 9:4537-4551.

Kerkhoff, A. J., and B. J. Enquist. 2006. Ecosystem allometry: the scaling of nutrient stocks and primary productivity across plant communities. Ecology Letters 9:419-427.

Kerkhoff, A. J., B. J. Enquist, J. J. Elser, and W. F. Fagan. 2005. Plant allometry, stoichiometry and the temperaturedependence of primary productivity. Global Ecology and Biogeography 14:585-598.

Kitayama, K., S. I. Aiba, M. Takyu, N. Majalap, and R. Wagai. 2004. Soil phosphorus fractionation and phosphorus- use efficiency of a Bornean tropical montane rain forest during soil aging with podozolization. Ecosystems 7:259-274.

Kobe, R. K., C. A. Lepczyk, and M. Iyer. 2005. Resorption efficiency decreases with increasing green leaf nutrients in a global data set. Ecology 86:2780-2792.

Kozovits, A. R., M. M. C. Bustamante, C. R. Garofalo, S. Bucci, A. C. Franco, G. Goldstein, and F. C. Meinzer. 2007. Nutrient resorption and patterns of litter production and decomposition in a Neotropical Savanna. Functional Ecology 21:1034-1043.

Lamarque, J. F., et al. 2010. Historical (1850-2000) gridded anthropogenic and biomass burning emissions of reactive gases and aerosols: methodology and application. Atmospheric Chemistry and Physics 10:7017-7039.

Li, L. J., D. H. Zeng, R. Mao, and Z. Y. Yu. 2012. Nitrogen and phosphorus resorption of Artemisia scoparia, Chenopodium acuminatum, Cannabis sativa, and Phragmites communis under nitrogen and phosphorus additions in a semiarid grassland, China. Plant, Soil and Environment 58:446-451.

Li, P., Y. S. Yang, W. Han, and J. Fang. 2014. Global patterns of soil microbial nitrogen and phosphorus stoichiometry in forest ecosystems. Global Ecology and Biogeography 23(9):979-987.

Lovelock, C. E., I. C. Feller, M. C. Ball, J. Ellis, and B. Sorrell. 2007. Testing the growth rate vs. geochemical hypothesis for latitudinal variation in plant nutrients. Ecology Letters 10:1154-1163.

Lu, X. T., G. T. Freschet, D. F. B. Flynn, and X. G. Han. 2012. Plasticity in leaf and stem nutrient resorption proficiency potentially reinforces plant-soil feedbacks and microscale heterogeneity in a semi-arid grassland. Journal of Ecology 100:144-150.

Luo, Y., and X. Zhou. 2010. Deconvolution analysis to quantify autotrophic and heterotrophic respiration and their temperature sensitivities. New Phytologist 188:10-11.

Manzoni, S., and A. Porporato. 2009. Soil carbon and nitrogen mineralization: theory and models across scales. Soil Biology \& Biochemistry 41:1355-1379.

Manzoni, S., P. Taylor, A. Richter, A. Porporato, and G. I. Ågren. 2012. Environmental and stoichiometric controls on microbial carbon-use efficiency in soils. New Phytologist 196:79-91.

Manzoni, S., J. A. Trofymow, R. B. Jackson, and A. Porporato. 2010. Stoichiometric controls on carbon, nitrogen, and phosphorus dynamics in decomposing litter. Ecological Monographs 80:89-106.

Mao, W., Y. Li, J. Cui, X. Zuo, and X. Zhao. 2011. Variations in foliar nutrient resorption efficiency of different plant growth forms in a temperate sandy grassland. Polish Journal of Ecology 59:355-365.

Marklein, A. R., and B. Z. Houlton. 2012. Nitrogen inputs accelerate phosphorus cycling rates across a wide variety of terrestrial ecosystems. New Phytologist 193:696-704.

Martinelli, L. A., S. Almeida, I. F. Brown, M. Z. Moreira, R. L. Victoria, S. Filoso, C. A. C. Ferreira, and W. W. Thomas. 2000. Variation in nutrient distribution and potential nutrient losses by selective logging in a humid tropical forest of Rondonia, Brazil. Biotropica 32:597-613.

Martínez-Sánchez, J. L. 2005. Nitrogen and phosphorus resorption in a neotropical rain forest of a nutrient-rich soil. Revista de Biologia Tropical 53:353-359.

McFarland, A. M. S., and L. M. Hauck. 2004. Controlling phosphorus in runoff from long term dairy waste application fields. Journal of the American Water Resources Association 40:1293-1304. 
McGill, W. B., and C. V. Cole. 1981. Comparative aspects of cycling of organic $\mathrm{C}, \mathrm{N}, \mathrm{S}$ and $\mathrm{P}$ through soil organic matter. Geoderma 26:267-286.

McGroddy, M. E., T. Daufresne, and L. O. Hedin. 2004. Scaling of C:N:P stoichiometry in forests worldwide: implications of terrestrial Redfield-type ratios. Ecology 85:2390-2401.

Melillo, J. M., J. D. Aber, and J. F. Muratore. 1982. Nitrogen and lignin control of hardwood leaf litter decomposition dynamics. Ecology 63:621-626.

Miltner, A., P. Bombach, B. Schmidt-Brucken, and M. Kastner. 2012. SOM genesis: microbial biomass as a significant source. Biogeochemistry 111:41-55.

Moore, T. R., J. A. Trofymow, C. E. Prescott, J. Fyles, and B. D. Titus. 2006. Patterns of carbon, nitrogen and phosphorus dynamics in decomposing foliar litter in Canadian forests. Ecosystems 9:46-62.

Moorhead, D. L., G. Lashermes, and R. L. Sinsabaugh. 2012. A theoretical model of $\mathrm{C}$ - and $\mathrm{N}$-acquiring exoenzyme activities, which balances microbial demands during decomposition. Soil Biology \& Biochemistry 53:133-141.

Moorhead, D. L., and R. L. Sinsabaugh. 2006. A theoretical model of litter decay and microbial interaction. Ecological Monographs 76:151-174.

Mooshammer, M., et al. 2014a. Adjustment of microbial nitrogen use efficiency to carbon:nitrogen imbalances regulates soil N cycling. Nature Communications 5:3694.

Mooshammer, M., W. Wanek, S. Zechmeister-Boltenstern, and A. Richter. 2014b. Stoichiometric imbalances between terrestrial decomposer communities and their resources: mechanisms and implications of microbial adaptations to their resources. Frontiers in Microbiology 5:22.

Mosier, A. R., J. A. Morgan, J. Y. King, D. LeCain, and D. G. Milchunas. 2002. Soil-atmosphere exchange of $\mathrm{CH}_{4}, \mathrm{CO}_{2}$, $\mathrm{NO}_{x}$, and $\mathrm{N}_{2} \mathrm{O}$ in the Colorado shortgrass steppe under elevated $\mathrm{CO}_{2}$. Plant and Soil 240:201-211.

Mouginot, C., R. Karwamura, K. L. Matulich, R. Berlemont, S. D. Allison, A. S. Amend, and A. C. Martiny. 2014. Elemental stoichiometry of fungi and bacteria from grassland leaf litter. Soil Biology \& Biochemistry 76:278-285.

Mulder, C., et al. 2013. Connecting the green and brown worlds: elemental factors and trait-driven predictability of ecological networks. Advances in Ecological Research 49:69175.

Nambiar, E. K. S. 1987. Do nutrients retranslocate from fine roots? Canadian Journal of Forest Research 17:913-918.

Näsholm, T., A. Ekblad, A. Nordin, R. Giesler, M. Högberg, and P. Högberg. 1998. Boreal forest plants take up organic nitrogen. Nature 392:914-916.

Olander, L. P., and P. M. Vitousek. 2000. Regulation of soil phosphatase and chitinase activity by $\mathrm{N}$ and $\mathrm{P}$ availability. Biogeochemistry 49:175-190.

Ordonez, J. C., P. M. van Bodegom, J. P. M. Witte, I. J. Wright, P. B. Reich, and R. Aerts. 2009. A global study of relationships between leaf traits, climate and soil measures of nutrient fertility. Global Ecology and Biogeography 18:137149.

Palace, M., M. Keller, and H. Silva. 2008. Necromass production: studies in undisturbed and logged Amazon forests. Ecological Applications 18:873-884.

Parton, W., et al. 2007. Global-scale similarities in nitrogen release patterns during long-term decomposition. Science 315:361-364.

Peñuelas, J., et al. 2013a. Human-induced nitrogen-phosphorus imbalances alter natural and managed ecosystems across the globe. Nature Communications 4:2934.
Peñuelas, J., J. Sardans, J. M. Alcaniz, and J. M. Poch. 2009. Increased eutrophication and nutrient imbalances in the agricultural soil of NE Catalonia, Spain. Journal of Environmental Biology 30:841-846.

Peñuelas, J., et al. 2013b. Evidence of current impact of climate change on life: a walk from genes to the biosphere. Global Change Biology 19(8):2303-2338.

Peñuelas, J., J. Sardans, A. Rivas-Ubach, and I. A. Janssens. 2012. The human-induced imbalance between C, N and P in Earth's life system. Global Change Biology 18:3-6.

Pietsch, K. A., et al. 2014. Global relationship of wood and leaf litter decomposability: the role of functional traits within and across plant organs. Global Ecology and Biogeography 23(9):1046-1057.

Potter, C. S., and S. A. Klooster. 1997. Global model estimates of carbon and nitrogen storage in litter and soil pools: response to changes in vegetation quality and biomass allocation. Tellus Series B-Chemical and Physical Meteorology 49:1-17.

Powers, J. S., et al. 2009. Decomposition in tropical forests: a pan-tropical study of the effects of litter type, litter placement and mesofaunal exclusion across a precipitation gradient. Journal of Ecology 97:801-811.

Prosser, J. I., et al. 2007. Essay: the role of ecological theory in microbial ecology. Nature Reviews Microbiology 5:384-392.

Read, D. J., editor. 1991. Mycorrhizas in ecosystems: nature's response to the "law of the minimum". CAB International, Kew, UK.

Reed, S. C., A. R. Townsend, E. A. Davidson, and C. C. Cleveland. 2012. Stoichiometric patterns in foliar nutrient resorption across multiple scales. New Phytologist 196:173180.

Regan, K., C. Kammann, K. Hartung, K. Lenhart, C. Mueller, L. Philippot, E. Kandeler, and S. Marhan. 2011. Can differences in microbial abundances help explain enhanced $\mathrm{N}_{2} \mathrm{O}$ emissions in a permanent grassland under elevated atmospheric $\mathrm{CO}_{2}$ ? Global Change Biology 17:3176-3186.

Reich, P. B., S. E. Hobbie, T. Lee, D. S. Ellsworth, J. B. West, D. Tilman, J. M. H. Knops, S. Naeem, and J. Trost. 2006. Nitrogen limitation constrains sustainability of ecosystem response to $\mathrm{CO}_{2}$. Nature 440:922-925.

Reich, P. B., and J. Oleksyn. 2004. Global patterns of plant leaf $\mathrm{N}$ and $\mathrm{P}$ in relation to temperature and latitude. Proceedings of the National Academy of Sciences USA 101:11001-11006.

Richardson, S. J., R. B. Allen, and J. E. Doherty. 2008. Shifts in leaf $\mathrm{N}: \mathrm{P}$ ratio during resorption reflect soil $\mathrm{P}$ in temperate rainforest. Functional Ecology 22:738-745.

Richardson, S. J., D. A. Peltzer, R. B. Allen, and M. S. McGlone. 2005. Resorption proficiency along a chronosequence: responses among communities and within species. Ecology 86:20-25.

Rivas-Ubach, A., J. Sardans, M. Perez-Trujillo, M. Estiarte, and J. Penuelas. 2012. Strong relationship between elemental stoichiometry and metabolome in plants. Proceedings of the National Academy of Sciences USA 109:4181-4186.

Saggar, S., R. L. Parfitt, G. Salt, and M. F. Skinner. 1998. Carbon and phosphorus transformations during decomposition of pine forest floor with different phosphorus status. Biology and Fertility of Soils 27:197-204.

Sardans, J., and J. Peñuelas. 2012. The role of plants in the effects of global change on nutrient availability and stoichiometry in the plant-soil system. Plant Physiology 160:1741-1761.

Sardans, J., and J. Peñuelas. 2013. Tree growth changes with climate and forest type are associated with relative allocation 
of nutrients, especially phosphorus, to leaves and wood. Global Ecology and Biogeography 22:494-507.

Sardans, J., A. Rivas-Ubach, and J. Peñuelas. 2012a. The $\mathrm{C}: \mathrm{N}: \mathrm{P}$ stoichiometry of organisms and ecosystems in a changing world: a review and perspectives. Perspectives in Plant Ecology, Evolution and Systematics 14:33-47.

Sardans, J., A. Rivas-Ubach, and J. Peñuelas. 2012b. The elemental stoichiometry of aquatic and terrestrial ecosystems and its relationships with organismic lifestyle and ecosystem structure and function: a review and perspectives. Biogeochemistry 111:1-39.

Sasaki, T., Y. Yoshihara, U. Jamsran, and T. Ohkuro. 2010. Ecological stoichiometry explains larger-scale facilitation processes by shrubs on species coexistence among understory plants. Ecological Engineering 36:1070-1075.

Saura-Mas, S., M. Estiarte, J. Penuelas, and F. Lloret. 2012. Effects of climate change on leaf litter decomposition across post-fire plant regenerative groups. Environmental and Experimental Botany 77:274-282.

Schimel, J. P., and M. N. Weintraub. 2003. The implications of exoenzyme activity on microbial carbon and nitrogen limitation in soil: a theoretical model. Soil Biology \& Biochemistry 35:549-563.

Schindlbacher, A., A. Rodler, M. Kuffner, B. Kitzler, A. Sessitsch, and S. Zechmeister-Boltenstern. 2011. Experimental warming effects on the microbial community of a temperate mountain forest soil. Soil Biology \& Biochemistry 43:1417-1425.

Schindlbacher, A., S. Wunderlich, W. Borken, B. Kitzler, S. Zechmeister-Boltenstern, and R. Jandl. 2012. Soil respiration under climate change: prolonged summer drought offsets soil warming effects. Global Change Biology 18:2270-2279.

Schneider, T., K. M. Keiblinger, E. Schmid, K. SterflingerGleixner, G. Ellersdorfer, B. Roschitzki, A. Richter, L. Eberl, S. Zechmeister-Boltenstern, and K. Riedel. 2012. Who is who in litter decomposition? Metaproteomics reveals major microbial players and their biogeochemical functions. ISME Journal 6:1749-1762.

Schreeg, L. A., M. C. Mack, and B. L. Turner. 2013. Nutrientspecific solubility patterns of leaf litter across 41 lowland tropical woody species. Ecology 94:94-105.

Silla, F., and A. Escudero. 2006. Coupling N cycling and N productivity in relation to seasonal stress in Quercus pyrenaica Willd. saplings. Plant and Soil 282:301-311.

Silver, W. L., and R. K. Miya. 2001. Global patterns in root decomposition: comparisons of climate and litter quality effects. Oecologia 129:407-419.

Simpson, A. J., M. J. Simpson, E. Smith, and B. P. Kelleher. 2007. Microbially derived inputs to soil organic matter: Are current estimates too low? Environmental Science \& Technology 41:8070-8076.

Sinsabaugh, R. L., and J. J. Follstad Shah. 2011. Ecoenzymatic stoichiometry of recalcitrant organic matter decomposition: the growth rate hypothesis in reverse. Biogeochemistry 102:31-43.

Sinsabaugh, R. L., and J. J. Follstad Shah. 2012. Ecoenzymatic stoichiometry and ecological theory. Annual Review of Ecology, Evolution, and Systematics 43:313-343.

Sinsabaugh, R. L., B. H. Hill, and J. J. F. Shah. 2009. Ecoenzymatic stoichiometry of microbial organic nutrient acquisition in soil and sediment. Nature 462:795-798.

Sinsabaugh, R. L., et al. 2008. Stoichiometry of soil enzyme activity at global scale. Ecology Letters 11:1252-1264.

Sinsabaugh, R. L., S. Manzoni, D. L. Moorhead, and A. Richter. 2013. Carbon use efficiency of microbial communi- ties: stoichiometry, methodology and modelling. Ecology Letters 16:930-939.

Sinsabaugh, R. L., and D. L. Moorhead. 1994. Resource allocation to extracellular enzyme production: a model for nitrogen and phosphorus control of litter decomposition. Soil Biology \& Biochemistry 26:1305-1311.

Sistla, S. A., E. B. Rastetter, and J. P. Schimel. 2014. Responses of a tundra system to warming using SCAMPS: a stoichiometrically coupled, acclimating microbe-plant-soil model. Ecological Monographs 84:151-170.

Sistla, S. A., and J. P. Schimel. 2012. Stoichiometric flexibility as a regulator of carbon and nutrient cycling in terrestrial ecosystems under change. New Phytologist 196:68-78.

Sloan, V. L., B. J. Fletcher, M. C. Press, M. Williams, and G. K. Phoenix. 2013. Leaf and fine root carbon stocks and turnover are coupled across Arctic ecosystems. Global Change Biology 19:3668-3676.

Smith, A. C., J. S. Bhatti, H. Chen, M. E. Harmon, and P. A. Arp. 2011. Modelling above- and below-ground mass loss and $\mathrm{N}$ dynamics in wooden dowels (LIDET) placed across North and Central America biomes at the decadal time scale. Ecological Modelling 222:2276-2290.

Smith, V. H. 2002. Effects of resource supplies on the structure and function of microbial communities. Antonie Van Leeuwenhoek International Journal of General and Molecular Microbiology 81:99-106.

Sterner, R. W. 1990. The ratio of nitrogen to phosphorus resupplied by herbivores: zooplankton and the algal competitive arena. American Naturalist 136:209-229.

Sterner, R. W., and J. J. Elser. 2002. Ecological stoichiometry: the biology of elements from molecules to the biosphere. Princeton University Press, Princeton, New Jersey, USA.

Strickland, M. S., E. Osburn, C. Lauber, N. Fierer, and M. A. Bradford. 2009. Litter quality is in the eye of the beholder: initial decomposition rates as a function of inoculum characteristics. Functional Ecology 23:627-636.

Strickland, M. S., and J. Rousk. 2010. Considering fungal: bacterial dominance in soils: methods, controls, and ecosystem implications. Soil Biology \& Biochemistry 42:1385-1395.

Sullivan, P. F., S. J. T. Arens, R. A. Chimner, and J. M. Welker. 2008. Temperature and microtopography interact to control carbon cycling in a high arctic fen. Ecosystems 11:6176.

Sullivan, P. F., M. Sommerkorn, H. M. Rueth, K. J. Nadelhoffer, G. R. Shaver, and J. M. Welker. 2007. Climate and species affect fine root production with long-term fertilization in acidic tussock tundra near Toolik Lake, Alaska. Oecologia 153:643-652.

Talbot, J. M., and K. K. Treseder. 2012. Interactions among lignin, cellulose, and nitrogen drive litter chemistry-decay relationships. Ecology 93:345-354.

Tempest, D. W., and O. M. Neijssel. 1992. Physiological and energetic aspects of bacterial metabolite overproduction. FEMS Microbiology Letters 100:169-176.

Thomas, S. C., and A. R. Martin. 2012. Carbon content of tree tissues: a synthesis. Forests 3:332-352.

Thrall, P. H., M. E. Hochberg, J. J. Burdon, and J. D. Bever. 2007. Coevolution of symbiotic mutualists and parasites in a community context. Trends in Ecology \& Evolution 22:120126.

Tian, H. Q., G. S. Chen, C. Zhang, J. M. Melillo, and C. A. S. Hall. 2010. Pattern and variation of C:N:P ratios in China's 
soils: a synthesis of observational data. Biogeochemistry 98:139-151.

Treseder, K. K., and P. M. Vitousek. 2001. Effects of soil nutrient availability on investment in acquisition of $\mathrm{N}$ and $\mathrm{P}$ in Hawaiian rain forests. Ecology 82:946-954.

Trofymow, J. A., et al. 2002. Rates of litter decomposition over 6 years in Canadian forests: influence of litter quality and climate. Canadian Journal of Forest Research 32:789804.

Urabe, J., and Y. Watanabe. 1992. Possibility of $\mathrm{N}$ or $\mathrm{P}$ limitation for planktonic cladocerans: an experimental test. Limnology and Oceanography 37:244-251.

van Geffen, K. G., L. Poorter, U. Sass-Klaassen, R. S. P. van Logtestijn, and J. H. C. Cornelissen. 2010. The trait contribution to wood decomposition rates of 15 Neotropical tree species. Ecology 91:3686-3697.

van Heerwaarden, L. M., S. Toet, and R. Aerts. 2003. Nitrogen and phosphorus resorption efficiency and proficiency in six sub-arctic bog species after 4 years of nitrogen fertilization. Journal of Ecology 91:1060-1070.

Veraart, A. J., J. J. M. de Klein, and M. Scheffer. 2011. Warming can boost denitrification disproportionately due to altered oxygen dynamics. PLoS ONE 6(3):e18508.

Vergutz, L., S. Manzoni, A. Porporato, R. F. Novais, and R. B. Jackson. 2012. Global resorption efficiencies and concentrations of carbon and nutrients in leaves of terrestrial plants. Ecological Monographs 82:205-220.

Vitousek, P. M. 1998. Foliar and litter nutrients, nutrient resorption, and decomposition in Hawaiian Metrosideros polymorpha. Ecosystems 1:401-407.

Vitousek, P. M., and R. W. Howarth. 1991. Nitrogen limitation on land and in the sea: how can it occur? Biogeochemistry 13:87-115.

Vitousek, P. M., S. Porder, B. Z. Houlton, and O. A. Chadwick. 2010. Terrestrial phosphorus limitation: mechaEcological Applications 20:5-15.

Walker, T. W., and J. K. Syers. 1976. Fate of phosphorus during pedogenesis. Geoderma 15:1-19.

Wallander, H., L. Johansson, and J. Pallon. 2002. PIXE analysis to estimate the elemental composition of ectomycorrhizal rhizomorphs grown in contact with different minerals in forest soil. FEMS Microbiology Ecology 39:147-156.

Wallander, H., L. O. Nilsson, D. Hagerberg, and U. Rosengren. 2003. Direct estimates of C:N ratios of ectomycorrhizal mycelia collected from Norway spruce forest soils. Soil Biology \& Biochemistry 35:997-999.

Wang, Y. P., R. M. Law, and B. Pak. 2010. A global model of carbon, nitrogen and phosphorus cycles for the terrestrial biosphere. Biogeosciences 7:2261-2282.

Wardle, D. A., R. D. Bardgett, J. N. Klironomos, H. Setala, W. H. van der Putten, and D. H. Wall. 2004. Ecological nisms, implications, and nitrogen-phosphorus interactions.

linkages between aboveground and belowground biota. Science 304:1629-1633.

Weedon, J. T., W. K. Cornwell, J. H. C. Cornelissen, A. E. Zanne, C. Wirth, and D. A. Coomes. 2009. Global metaanalysis of wood decomposition rates: a role for trait variation among tree species? Ecology Letters 12:45-56.

Welker, J. M., J. T. Fahnestock, P. F. Sullivan, and R. A. Chimner. 2005. Leaf mineral nutrition of Arctic plants in response to warming and deeper snow in northern Alaska. Oikos 109:167-177.

Wright, I. J., et al. 2004. The worldwide leaf economics spectrum. Nature 428:821-827.

Xu, R., I. C. Prentice, R. Spahni, and H. S. Niu. 2012. Modelling terrestrial nitrous oxide emissions and implications for climate feedback. New Phytologist 196:472-488.

Xu, X. F., P. E. Thornton, and W. M. Post. 2013. A global analysis of soil microbial biomass carbon, nitrogen and phosphorus in terrestrial ecosystems. Global Ecology and Biogeography 22:737-749.

Yang, X., P. E. Thornton, D. M. Ricciuto, and W. M. Post. 2014. The role of phosphorus dynamics in tropical forests: a modeling study using CLM-CNP. Biogeosciences 11:16671681.

Yang, Y., G. Wang, L. Yang, and J. Guo. 2013. Effects of drought and warming on biomass, nutrient allocation, and oxidative stress in Abies fabri in eastern Tibetan Plateau. Journal of Plant Growth Regulation 32:298-306.

Yu, Q., J. J. Elser, N. He, H. Wu, Q. Chen, G. Zhang, and X. Han. 2011. Stoichiometric homeostasis of vascular plants in the Inner Mongolia grassland. Oecologia 166:1-10.

Yuan, Z., and H. Y. H. Chen. 2009. Global trends in senescedleaf nitrogen and phosphorus. Global Ecology and Biogeography 18:532-542.

Yuan, Z. Y., and H. Y. H. Chen. 2010. Fine root biomass, production, turnover rates, and nutrient contents in boreal forest ecosystems in relation to species, climate, fertility, and stand age: literature review and meta-analyses. Critical Reviews in Plant Sciences 29:204-221.

Yuan, Z. Y., H. Y. H. Chen, and P. B. Reich. 2011. Globalscale latitudinal patterns of plant fine-root nitrogen and phosphorus. Nature Communications 2:344.

Zhang, D. Q., D. F. Hui, Y. Q. Luo, and G. Y. Zhou. 2008. Rates of litter decomposition in terrestrial ecosystems: global patterns and controlling factors. Journal of Plant Ecology $1: 85-93$.

Zhang, H., W. Yuan, W. Dong, and S. Liu. 2014. Seasonal patterns of litterfall in forest ecosystem worldwide. Ecological Complexity 20:240-247.

Zotz, G. 2004. The resorption of phosphorus is greater than that of nitrogen in senescing leaves of vascular epiphytes from lowland Panama. Journal of Tropical Ecology 20:693696.

\section{Supplemental Material}

\section{Ecological Archives}

The Appendix is available online: http://dx.doi.org/10.1890/14-0777.1.sm 